\title{
MOLYBDENUM IN THE NUTRITION OF THE RABBIT AND RAT
}

\author{
By \\ LEWIS ROBERTS ARRINGTON
}

\begin{abstract}
A DISSERTATION PRESENTED TO THE GRADUATE COUNCIL OF THE UNIVERSITY OF FLORIDA

IN PARTIAL FULFILMENT OF THE REQUIREMENTS FOR THE DEGREE OF DOCTOR OF PHILOSOPHY
\end{abstract}

UNIVERSITY OF FLORIDA

June, 1952 
UNIVERSITY OF FLORIDA

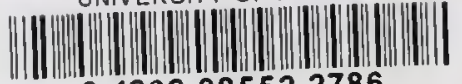

31262085522786 


\section{ACKIO:LEDGEZITS}

In the planning of this rescarch, in conducting the experiments and in preparation of this dissertation, acknowledgement is made of the help and counsel of many individuals. The author wishes to express sincere appreciation to all those who have contributed to the corpletion of this dissertation.

Dr. George K. Davis has made available necessary facilities for this research and as chairman of the supervisory comittee has Euided the research program.

Dr. R. E. Becleer, Dr. T. Stearns, Dr. Ray I. Shirley, Dr. H. ग. "allace, Dr. A. F. lioval and Dr. R. I. Mnerson served as members of the special supervisory cormittec.

1.r. Sam. L. Hansard has given material aid and advice in the experiment involving the use of radioactive isotopes.

Ifr. J. D. Burke made blood volume determinations on the experimental rabbits.

Dr. John F. Feaster has given personal assistance and com operation.

Vir. John T. I.cCall and other nembers of the staff of the liutrition Laboratory have aided in the laboratory analyses.

Dr. Wax 1. Jeter aided in the planning of some of the experiments and other raduate students have assisted in other phases of the research.

"r. Juan 3-7a, lir. Richard Sparrow and "r. !'ax Garhart havo contributed by attenline the exmerimental animals. 


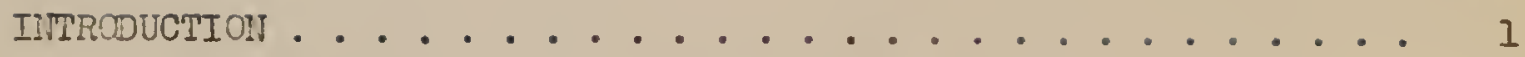

llolybdemum in PIant and Animal lutrition ....... 2

Lolybdenum and Copper Interrelationships in

the inimal Organism. .............. 5

lolybdenun and Phosphorus letabolism........ 7

EXPRDETT I. Iolybdemu Toxic1ty in the Rabbit....... 10

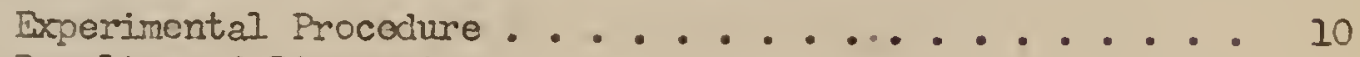

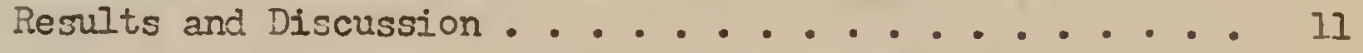

EXPEPIIMIT II. The Effects of Varyine Levels of "oljodemm

upon the Grorth of Rabbits .......... 21

Experimental Procedure ............ 21

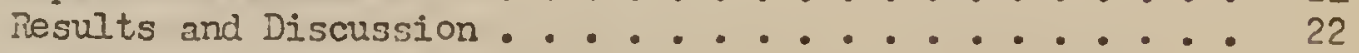

EXPEPIIITIT III. The Effects of Varyine Levels of :olybdemon

upon the Hemoglobin, Red Blood Cell count

and Blood Volune of Rabbits ........... 25

Experimental Procedure ................. 25

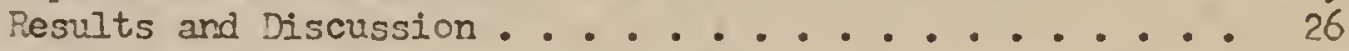

EXEREIEIT IV. The Role of Copper in rolation to Holybdemu

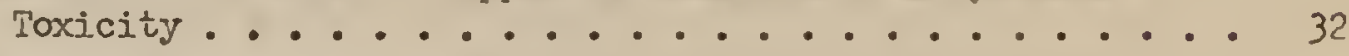

Experimental Procedure . . . . . . . . 32

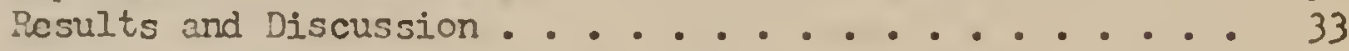

EXPERI:ITIT $\nabla$. The Effects of Low Intakes of Dietary l'olybdemm

and of Vitamins $\mathrm{A}$ and $\mathrm{D}$ in those Diets upon tho Gro th

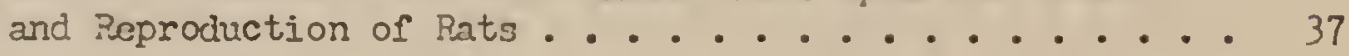

Experimental Procedure . . . . . . . . 37

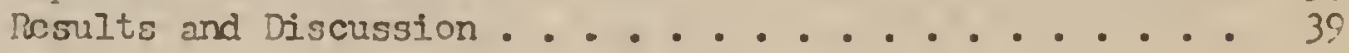

EXPEDISIT VI. Phosphorus letabolism and Distribution of

Thosphoms 32 in the Rabit and Rat ........ $4_{4} 6$

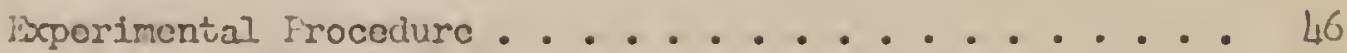

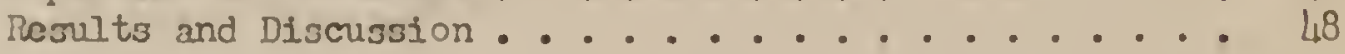


GEIERAI SUILARY . . . . . . . . . . . . 58

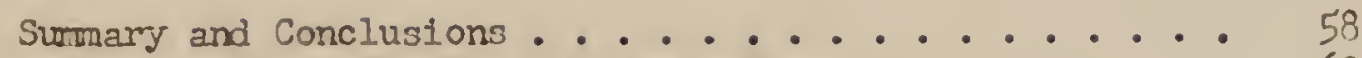

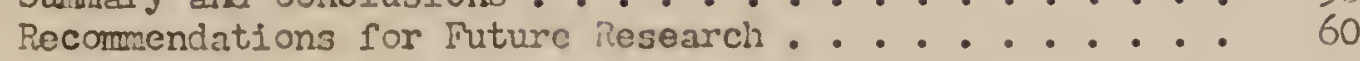

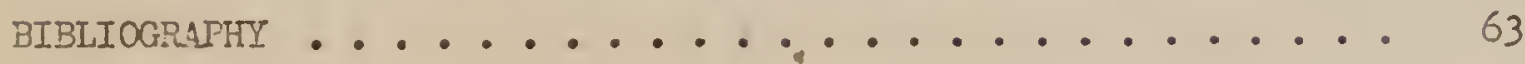

\section{List of Tables}

Table

1. Sumary of lolybdemun Toxicity Symtoms in 'abhits . . . 12

2. Lean Veckly lieights of Experinenta] Rabbits ...... 23

3. l'ean Hemoglobin Values for Experinental Rabuits ..... 27

4. Hemoglobin of Some Individual Pabbits neccivine

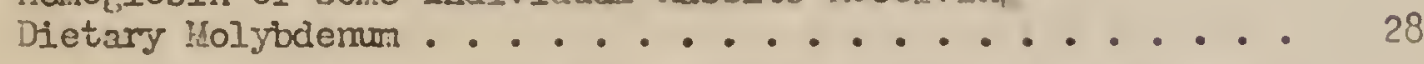

5. llemoglobin and Red Blood Cell Counts of Individual Rabbits .

6. Blood Volune, Hemorilobin and Rod Rloat cells of liomal Rabbits and Rabbits Anenic with Molybdemun Toxicity ....

7. Iffects of Copper Therapy upon ieicht, ilemorlobin Ievel, and Red Cell Count of Rabbits Affected with "olytdemm

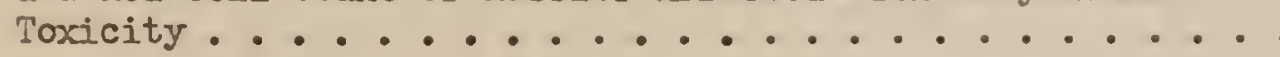

8. Accumulation of Copper in the Livers of Sxperimental Rabbits on Difforent I'olybdemum and Copper Intakes . . . .

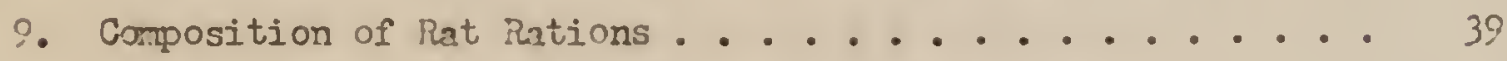

10. "Eean "eel:ly Weights and Total Gain of linle Rats ..... 40

11. Lean Weekly "eirhts and Totar Gatn of Female rats .... 41

12. Fertility of liale and Fomale Rats necoivin Dietary Lolybdemm and Comper

13. Effects of Dictary Wol;bromes and Hothors of Adninistration upon the Excretion of Fhomphorus 32 and of Total Phosinoms by the Rabbit ................ 
11. Effects of Dietary !'olybdemon, hge and Tine after Dosing upon the Excretion of Orally Administered Thosphorus 32

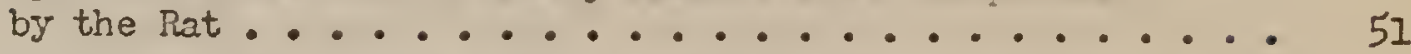

15. Iffects of Volybdenum upon the Deposition of Fhosphorus 32 in Selected Tissues of the Pabbit .......... 52

16. Effects of Dietary Molybdemm upon the Deposition of Fhosphorus 32 and Total Phosphorus in Selected Tissues of Mature Rats .................

17. Deposition of Ihosphorus 32 and Amount of Totel Thosphorus in Selected Tissues of Young Rats .......... 54

18. Total Phosphorus Content of Ferrur Bones of Pabbits Fed Varying Levels of liolybdemu and Copper . . . . . . .

\section{Iist of mlustrations}

Firure

1. Rabbits Receiving Dictary "olybdemon and Schibitin Typical Ilopecia ............ Il

2. Young Rabbits Bxhibiting Front Ier :bnormality ...... 16

3. Bones from Young Rabit Shorinf Pront Ler Abnormality . . 19

4. Forelegs of Young Rabbit Shorine Shifted Carpus Joint . . 19

5. lale Rats on Molybdemum Diets Exhibiting lopecia

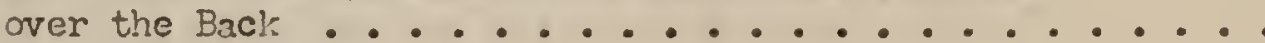




\section{MTRRODUCTIOIS}

Although molybdemum is one of the scarcer mineral elements, its corpounds are videly distributed in nature. It occurs in subterranean deposits and in small but varying arounts in the surface layers of soil where it is available to plants. It is present in plant and animal tissues. Its wide occurrence in plants and aninals has stimulated much interest in evaluating, its function in these forms of life. Thus it is established that molydemm is essential to the growth of certain microor ranisms and many higher plants. It is not knom to be a dietary requirements for any animal species; rather, its presence is hamful under certain conditions.

Animal species vary in their tolerance to molybdenum in the diet, moinants boing less tolerant than are non-muinants. The action of molybdemm in the animal body whereby the toxicity is pro duced is not lnom.

There are areas of the morld where the presence of molybdenum in the soil and in the plants makes grazing hazardous or inpossible. Wile these areas are rather restricted, a potential problem exists which cannot be limited to areas now affected. Since many plants respond to the presence of molybdemm and reflect this to some extent in their tissucs, the practice of molybdenum fertilization creates a problem mich may be extended to other areas.

This study has been designed to extend observations of the effects of dictary molybdemen to the rabbit and expand studics irith 
the rat. The herbivorous dietary habit of the rabit and the size of the animal make it possible to study a herbivorous species under laboratory conditions. The difference in the response of ruminant and non-ruminant animals toward molybdenum malies it desirable to establish the relative position of this herbivorous, but non-ruminant species, with regard to its tolerance for dietary molybdemum.

\section{Molyodemum in Plant and Animal lintrition}

The ride distribution of nolybdenum in the plant and animal kingdom has been observed by several investigators. In 1931 ter Heulen $(59,60)$ reported the presence of molybdemn in microorganisms, soil, wrood, peat and in the blood, liver and spleen of domestic animals and man. Since that tine it has been found in hens eggs $(32,56)$ and in human and coris milk $(4,33,34)$.

The role of molybdenum in the mutrition of certain microorganisms was recognized before its significance in higher plants was established (10). In 1931, Bortels (II) reported that molybdemun is essential to biolorical nitrogen fixation. Since that time there have been many reports of investigations which have established the role of molybdemum as a stimulant to growth and nitrogen fixation in certain microorganisms $(13,19,31,47,72,73)$.

Some hicher plants havo shom favorable response to the prosence of molybdemm in tho soil. Amon and Stout (5) in 1939 dernonstrated the need for molybdenum in the mutrients of tomato seedlings and later Its value for lettuce was established (16). l'olytodenum is requirod by many plants $(29,1: 6,64,77)$. Lecuminous plants exitbit a creater 
response to molybdemm than do non-legumes. In these plants it has been observed to increase growth or yield, to improve the color and stimulate nitrogen fixation $(1,2,12,48,78)$.

Under certain soil and climatic conditions, plants accumulate excessive quantities of molybdemm wich may become critical in relation to their use as pasture or hay crops. Some of these factors which may alter the accumulation of molybdemm have been established. $\Lambda$ species difference has been established from the observations that leguminous plants concentrate more of the soil molybdenum than do nonlefumes $(8,40,52)$. An alkaline reaction of the soil favors an increase of the element in plant tissues whereas very little molybdenum. is taken up under acid soil conditions $(3,8,53)$. Younf groring plants contain more molybdenum than mature plants on a dry matter basis $(8,37)$. The amount of the element in the soil is also a factor although its effect upon plant tissue accumulation is often masked by the form in which it is found and other soil conditions (53). Where those conditions exist, serious abnormalities in grazing cattle or sheep have been comon. Such abnomalities have been reported from areas in California and Southern Forida in tho United States and in ingland, Australia and New Zealand. While the conditions are not the same in all of these areas, the forage from these areas contains a relatively hich anount of molybdenum.

Beath and associates ( $(2)$ in 1935 observed certain abnomalitics in cattle which were erazinf pastures containing $39 \mathrm{ppm}$ molybdenum. The first specific description of pathological conditions in cattle 
which were attributed to excess molybdemm was made by Ferguson in 1938 (39). Since that time his observations have been confirmed and extended in the other areas of the world where cattle and sheep are sinilarly affected.

The extermal appearance of the plants gives no evidence of abnormality and only by analysis is the excess molybdemm detected. Then plants from an affected area become mature or are made into hay, the toxicity is much reduced. It is possible that the green forage contains a form of molybdenum which is more toxic or that it contains another substance mich renders the molybdemm more effective. When molybdate salts are fed to animals receiving dry hay and to those receiving green succulent feed, the toxicity is less severe or even absent in those receiving dry hay $(37,38,39)$.

The toxic symptoms wich have been observed in cattle and sheep are characterized by diarrhea, loss in weight, change in the color of the hair coat, anomia and eventual death unless removed from the affected area or treated $(8,17,25)$. Horses grazing on the same areas which cause trouble in ruminant animals are not affected (17, 39).

Investigations concerning the effects of dietary molyudenum have not boen linftod to farm animals. Studies have been undertalien usinf, laboratory animals, but theso have been principally confined to experinents using rats $(21,36,41,42,49,63,75)$. The results are in general agrocment that rats are more tolorant of diotary molytolenum than ruminant animals; nevertheless, rats aro subject to somo tordc 
effects of excess molybdem. The manifestations of the toxic symptoms observed in rats do not parailel those in cattle and sheep. Severe diarrhea and anemia which are common symptoms in ruminants have not been consistently produced in rats.

liolybdemm as nolybdemm trioxide, calcium moljbdate, and armonium molybdate supplying 1200 to 6000 milligrams of molybdenum per lilogram was fatal to guinea pigs and rats (36). An equivalent mount of molybdenite was not fatal.

Other abnormalities which have been more recently attributed to moljojdemm are interferences with normal reproduction. Jeter (42) in 195 I found that a high percentare of male rats which were fed 80 and $I_{10} \mathrm{ppm}$ nolybdemm in the dict were sterile. In fomale rats fed the same rations there was an irregular estrus cycle. Thomas and L̈oss (76) have observed infertility and a lack of libido in young dairy bulls. In both of these species, the male infertility was accompanied by damare to the germinal epithelium and interstitial cells of the testes.

\section{Wolybdenum and Copper Interrelationships} in the Animal Orfanism

One of the most significant discoveries with regard to molyto demu toxicity is the therapeutic action of copper. When adequate anounts of copper are present in the dietary (the quantity necessary depends upon the nolytodemm present) the symptoms of nolybdemum toxicity soldom develop. Furthermore, toxic sysptons wilch may be present can be corrected with copper supplementation. This action of copper has been 
demonstrated in practically all species for which a toxdcity has been reported $(25,37,38,63)$. ihen there is an excess of nolybdemu and a deficiency of copper in the soil which is normally reflected in the plant, the adverse effects upon animals grazing these plants can be corrected by copper fertilization (25).

The abnomalities caused by copper deficiency and molybdenum excess are such that it is frequently difficult to distinguish betwreen the tro $(28,74)$. Because of the therapeutic effect of copper, it might be expected that excess molybdemu should deplete the body of its stores of copper and create a copper deficiency. Such a decrease has not been consistently observed. Dick and Bull (30) reported a decrease in the copper content of the liver of erres which were fed copper and molybdemu, but others $(51,58)$ have observed an increase in liver copper under similar conditions. "inen the copper intake is below that necessary to insure positive copper balance, molybdenum will reduce the copper stores more rapidly. However, when adequate copper is provided, molybdemm causes an increase in the coprer store but at the same tine may precipitate the symptons of copper deficiency. Lolybdemm apparently tends either to fix the copner in a form which is not available to the tissues or to antagonize by hindrance the copper containing enzymes (58).

The physiological action of molybdemu and the mechantsm through which copper exerts its therapeutic effect are unlonom. Based upon some evidence, several different theories have boon proposed wich are desifnod to explain these functions. l!ckoran and associates (55) 
belicve that the activity of bacteria in the gnstrointestinal tract is controlled by catechols and that molybdemm renders the catechols ineffective by formation of complexes. The uncontrolled activity of the bacteria thus causes the severe diarrhea. The therapoutic effect of copper is thought to be due to its toxic action upon bacteria. This theory is not menerally accepted in light of present knowledge. iiisconsin morkers (63) have suggested that the action of molybdemm may be due to the formation of a copper molybdate complex which is poorly absorbed. The effect of molybdates upon certain enzymes in vitro and the interaction of copper and molybdemum in vivo have sugrested to others that molybdomm interferes with some enzyme systerns, particularly the copper enzymes (7, 50). None of these theories has yet been supported by adequate evidence to explain the action of molybdemm.

\section{Molybdemur and Phosphoms Metabolism}

Anone the symptoms of molybdemm toxicity which have been observed in cattle has been an abnomal skeletal development. This has been accompanied by other evidences of abnomal phosphomus metabolism. In areas of Florida where there is a deficiency of copper, and molybdemum is prescnt, abnormal bone formation has resulted (26, 27). Spccific symptoms have becn stiffness, broken bones, enlared joints, crosion of the joints and a condition resembling rickets in young animals and ostcomalatia in older cattle. Thomas and lioss (76) have obscrvod stiffness and bone involvement in younc dairy bulls fed molybdemm. The plasma inorganic phosphoms and sorum phosphatase vere 
normal, but there was erosion of some joints and union and fusion in one joint. The ash content of rib bones was nomal. The stiffness and brittleness of bones which have been observed by others (17, 25, 26) also reflect abnormal bone development, possibly related in some manner to the metabolism of molybdenum.

Some of the effects of molybdenum upon absorption and excretion of phosphorus have been studied using radioactive phosphorus32. Then phosphorus and molyodemum were administered simultaneously to rats, the phosphorus uptake was increased. When molybdenum was fed previously there was the reverse effect upon phosphorus (21). The normal excretion of phosphorus by cattle where most of the phosphorus is excreted in the urine has been observed to change to a pathway where more is excreted in feces when the animals were given copper and molybdenum supplements (63). Nio similar effect could be observed in rats, a].though there was a chance in the rate of excretion (69). These results further indicate some abnomality in phosphorus metabolism.

Other possible relationships between molybdenum and phosphorus metabolism have been show through the action of molybdate ions upon phosphatases. Bossard $(14,15,22)$ has reported an inhibitory effect of the molybdate ion upon certain phosphatases includinf, a slight inhibitory effect upon calf bono phosphatase. ilso observod was an increase in serum alkaline phosphatase and blood inorganic phosphorus in copper deficient cattle (26).

The literiture concerninf, molybdemm and its relation to other olements in the animal organism has been roviewed by sovoral nuthors. 
The relation of certain minerals to animal health has been reviewed by Passell (65) and the relation of mineral elements to health of mminants in Great Britain has been surmarized by Green (43). The role of molybdenu and other minerals in the mutrition of animals and plants has been more recently reviered by liarston ( 57 ). 


\section{EXPGRITITI I}

HOLYBDEMU:. TOYICITY IN! THE RABBIT

Some differences in species with relation to their tolcrance for molybdenum have been observed. Iimited studies with horses and swine have indicated a relatively hich tolerance for these species and the mumerous investigations with cattle and sheep show that these animals have a low tolcrance for molybdenum. Because of the different effects of molybdemu upon ruminant and non-ruminant animals, it appeared desirable to determine whether or not the element was toxic to rabbits and to establish its relative toxicity in this species. Upon the initiation of this study there had been no reported investigations of the effect of molybdenum upon rabbits. Smith and Ellis (70) have described the symptoms of simple copper deficiency in the rabbit, but there is no evidence that excess molybdemu was involved in the abnormality.

The objective of this experiment was to describe the effects of molybdenum excess upon rabbits.

\section{Experinental Procedure}

Inle and fenale Dutch rabbits of different ages were used for this expcriment. They wore maintained in metal cages with metal wire bottoms. The rabbitry was houscd in an open barn :Ith natural ventilation and without artificial hoat.

The basal ration for all treatments was a commercial ration in pcllet form (Staf-O-Life Rabult Fellets, manufactured by Royn 
Staf-C-Life lills, lemphis, Tennessee) and had promoted satisfactory Erowth for rabbits in this laboratory. Feed was given ad libitum and 2 ll unconsumed feed was removed every other day or more often if it becane dirty. Small quantities of fresh green feed were riven each wecl. Fresh water was supplied from class drinling bottles. lolybdenun was added to the basal ration as sodium molybdate $\left(\mathrm{lia}_{2} \mathrm{lfoO}_{4} \cdot 2 \mathrm{H}_{2} \mathrm{O}\right.$ ) in anounts calculated to provide $0.014,0.05,0.1,0.2$ and 0.4 per cont molybdemum. The basal ration contained 2.7 ppm molybdemu and $16.1 \mathrm{ppm}$ copper by anaiysis using the thiocyanatestannous chloride method (67) for molybdemm and the carbanate method (66) for copper. Molybdate salt was added to the pellets by spraying on an aqueous solution and allowing it to air dry. Analyses of composite samples made from the rations indicated that nt the higher levels of molybdemon the amount incorporated was slightly less than the calculated amount.

Thirty-four weanling rabbits six to soven weeks of age :zere placed on the experimental rations and six mature rabbits were changed from the basal ration to three of the treatment levels of nolybdemu. Observations rere made daily for any development of toxic symptoms and the order of appearance of any abnomalities was recorded.

\section{Results and Discussion}

Gross abnomalitics wich rere attributed to excess molybdemm developed in the rabbits fed 0.1 per cent or more molybdemu. Deaths resulted from the hirher levels of nolybdemun. A surmary of the results is presented in Table 1. All of the youn rabbits reccivinf 0.1 per 
cent molybdemum developed some symptoms of toxicity although the condition became severe in only three of these rabbits. These three were treated with copper when it became apparent that they would not survive without treatment. No detrinental effects of 0.1 per cent molybdenum :rere observed in the two mature rabbits over a period of eight weeks. Five-hundredths per cent molyodemum in the ration caused no gross abnomalities in any of the aninals. There was some evidence of retarded growth of the rabbits on this level of molytbdemm in the early weels after veaning. There was a slight loss of hair wich soon returned to nomal, but other symptoms of toxicity were absent. Ione of the rabbits receiving 0.014 per cent molybdenum developed abnomalities which could be attributed to molybdenum in the ration.

\section{TABLE 1}

SURARRY OF LOLYBDARU TOXICITY SYIPTOHS IN PABBITS

\begin{tabular}{|c|c|c|c|c|c|}
\hline Treatment & $\begin{array}{l}\text { lio. of } \\
\text { Rabbits }\end{array}$ & Deaths & Anemia & $\begin{array}{l}\text { Alopecia } \\
\text { and } \\
\text { Dermatosis }\end{array}$ & $\begin{array}{l}\text { Front log } \\
\text { Abnormality }\end{array}$ \\
\hline $\begin{array}{l}0.4 \% 1.0 . \\
0.2 \% 110 . \\
0.1 \% \text { 1.0. } \\
.05 \% \text { \% } 110 . \\
\text { C.014 } 20 . \\
\text { Basal }\end{array}$ & $\begin{array}{r}4 \\
5 \\
7 \\
5 \\
12 \\
7\end{array}$ & $\begin{array}{l}4 \\
4 \\
\vdots \cdots \\
0 \\
0 \\
0\end{array}$ & $\begin{array}{l}\text { present } \\
\text { present } \\
\text { present } \\
\text { absent } \\
\text { absent } \\
\text { absent }\end{array}$ & $\begin{array}{l}0 * \\
4 \\
5 \\
0 \\
0 \\
0\end{array}$ & $\begin{array}{l}1 \\
2 \\
2 \\
0 \\
0 \\
0\end{array}$ \\
\hline
\end{tabular}

* Deaths occurrod early and no alopecia observed.

* $*$ Sevoro toxic symptoms developed in threc rabbits with deaths probable but copper therapy was inftiated to prevent denth. 
The time of appearance of the abnormalitics varici from about fnur weels in the reanling rabits to several montis in the mature animals. Follo:ing the first apparances of the condition, the symorome became progressively worse and death usually occurred within two weeks.

The syndrome which developed was characterized by a decrease in feed intale, a decrease in reight gains or actual weight loss, roughening of the hair coat ith loss of hair beginning irith complete demudation over mall areas wich generally spread to practically the cntire body. The alopecia was accompnied by varyine degrees of dematosis with rough, dry, scaly skin. There was no evidence of shin infection or inflamation. Ancmia became severe and the animals soon died unless treated. In some young rabbits an abnomality in the front legg was prescnt.

The anemia, alopecia and dernatosis make the condition appear similar to the symtoms of cosper deficiency in rabbits described by Smith of al (70). In contrast to the simple copper deficiency symptoms, no crayine of the blacle hair in the rabbits on this exporiment vas observed. In Figure $I$ are pictures of rabbits cxhibiting tyoical alopecia.

Iimited observations :ere made of the sex interest of male rabbits. Two males on hish levels of molybdemm which were suffering from moderate and severe symptoms of toxicity demonstrated nomal sex interest when placed with females. This observation is in contrast to that made on young dairg bulls receivine, moljbdemum (76). The 

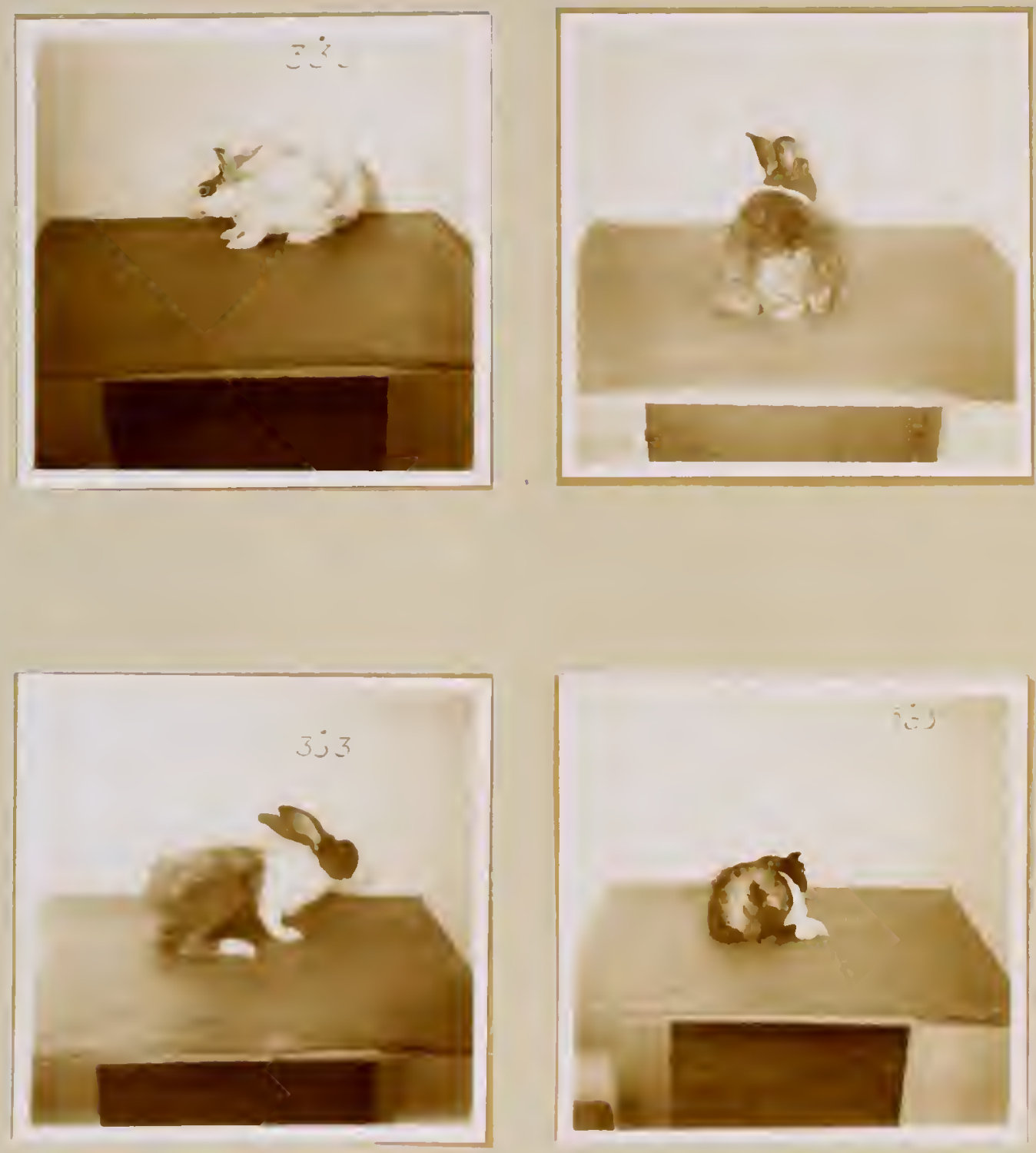

Timure 1. Youne, rabbits reccivine dietary molybdonum and cxhiviting typical alopccia. 
fertility of rabbits in this experiment was not detemined.

In each of the rabbits which devclonod the syndrome of toxicity, with two exceptions, the condition becane progressively worse until the aninal died or was eiven copper therapy. Fwo of the young rabbits developed moderately severe symptoms of toxicity but gradually recovered spontancously. The explanation for this is difficult, but several facts should be observed. The symptoms did not develop in the early weeks of the experinent as was comnon with the other reanling rabbits, so the animals were older when the abnormalitics were observed. The level of molybdemum ( 0.1 per cent) was borderline for toxicity in mature rabbits. The development of the toxicity was slow and the recovery was slower than the recovery observed with copper treatment. One of the more specific abnomalities not observed in other species "as a "brealk-dom" in the front legs of some young rabbits recciving hich levels of molybdemu. This condition occurred in five of the ten reanling rabbits thich developed othcr toxic symptoms. It did not appear in any of the mature rabbits nor any of the other yount rabbits after they had passed ten to elcven weeks of are.

In Finure? are pictures of typical rabbits mich cxhibit this foreler abnomality. The first evidence of this condition mas an apparent soreness and slight difficulty in walking. There was, horrever, no evidence of soreness when the leges were examined. The affected animals were observed to sit far bacl: on thcir rear legs and frequently rest the front legs in the feed cun in apparent effort to shlft the body ireight from the front feet. They soon became unable 

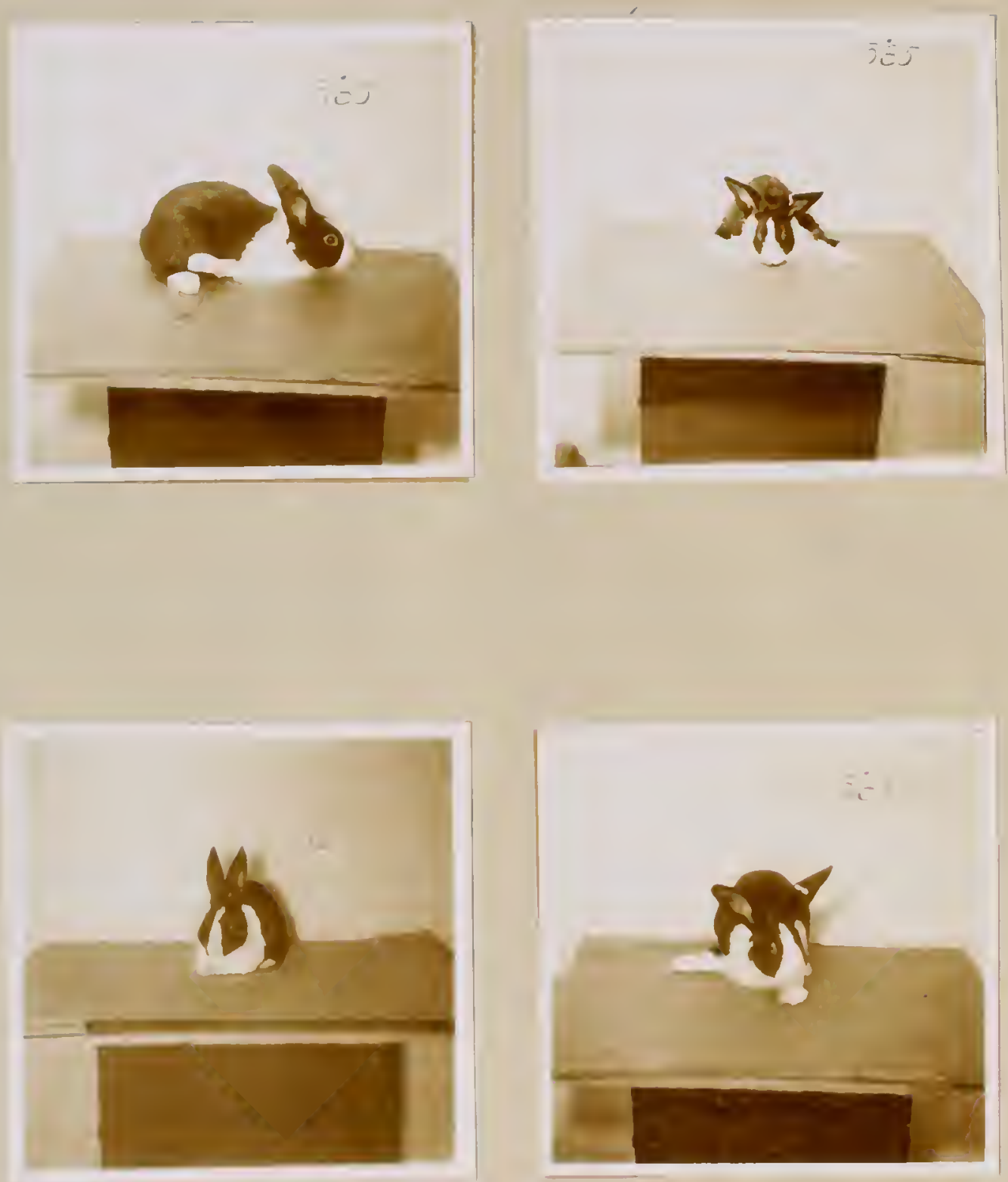

Firure ?. Young rabbits exhibitins, front leg abnomality. 
to maintain their weight; the legs spread outward and the forepart of the body rested on the floor. The ability to move the legs was not lost and in efforts to walt the lees simply slid on the floor. Tro of the rabbits thus affected were treated ith copper sulfate when the synptoms of toxicity becane severc. There was only slight inorovement in this condition while there ras complete recovery from all the other symptoms.

Examination of the bone as it was removed from a typical rabbit after sacrificing revealcd bending of the upper portion of the humerus and a strollen joint at the junction of the huremis and scapula (Figure 3). Apparently the tristing of the humerus permitted the legs to spread outward. Not all of the cases shorred gross bending of the bone or swollen joints and anparently a slight twisting of the bones permitted the lees to spread outirard.

llear the termination of this experiment somewhat different abnormalitics were obsorved in the front legs of two young rabbits which died with coccidiosis. These two aninals were receiving dietary molybdemen but they have not been included in the results described for the other experimental animals because of the presence of coccidiosis. The infection was accompanied by anorexia, diarrhea and other symptons which may have complicated the offects of molybdenum. In the case of one of these rabbits, the fect of both forelegs bent imiard at the carrus joint (Firure 2). An examination of the bonos as they were removed revonled that the carpus joint of both legs had shifted out of nlace and the articular surface of the radius was 
exposed (Figure 4). The tendons of both joints had slipped out of the nomal position. The scapulo-humoral joint of the right leg ras loose but had not shifted out of placc. There was no gross bending of the bones in this rabbit. In the other joung rabit receiving molybiemm wich died with coccidiosis, significant bending of the lower portion of the radius and ulna of one leg was observed. There was also slicht enlargement of the scapulo-humoral joint, but no slipped tendons. Some of the abnormalities of the forelces of rabbits in this experiment appear to be sinilar to the crooled front legs described by Smith et al $(35,71)$ and attributed to manganesc deficiency. In the manganese deficient rabbit, the crookedness was confined to the radius and uIna. Gross bending or tristing of these bones has not been a characteriatic of the rabbits in this study, although these bones in the lof of onc young rabbit wore thus affected. The results of this experiment do not, however, eliminate the possibility that a deficiency of manganese is involved and further studies should be made to compare these conditions. Deformities in the legs of rabbits fed a millk diet were obscrved as carly as 1926 by Brouwer (18), but the cause of the abnomality in these rabbits was not know.

In isceriment IV the results of copper thorapy aro prescnted. It should bo observed at this point, however, that the only symtom of molybdemm toxicity in these rabbits wich was not curcd by copper therany was abnomality of the forelers. Tro of the three rabbits mich were thus trated exhjbitied the tymical front leg "braal-dom". The condition in both rabbits improved slirhtly althourh all other 

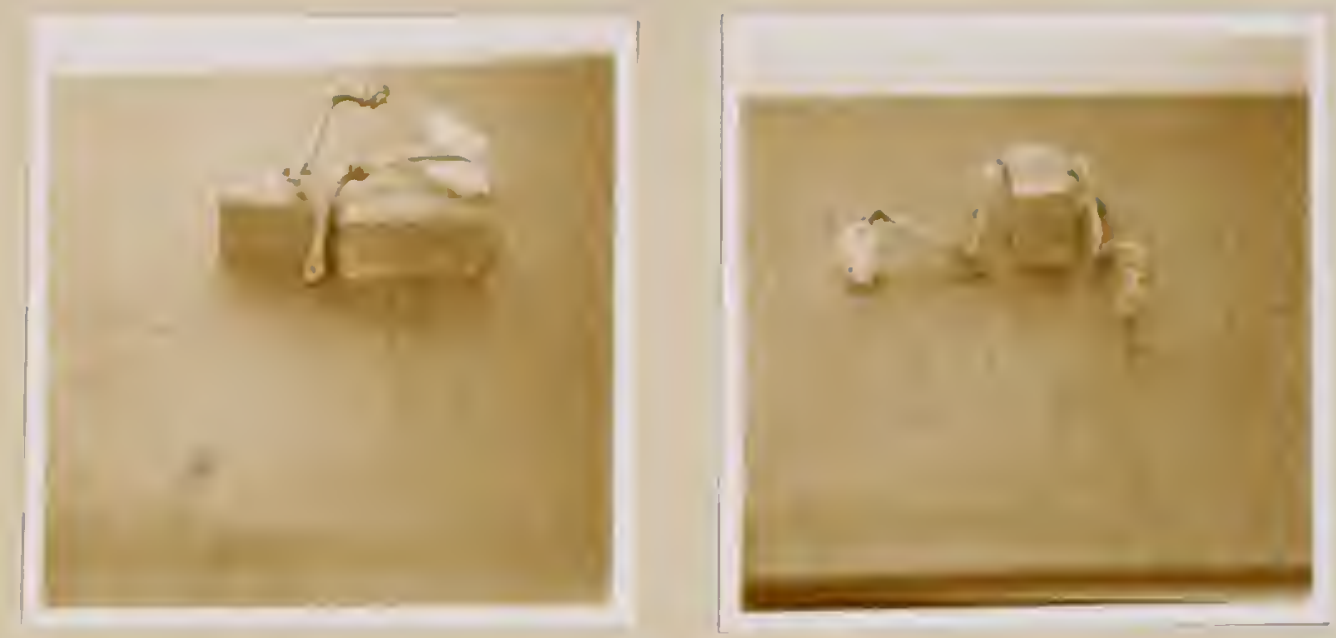

Figure 3. Bonos from young rabbit shoring front leg abnormality.

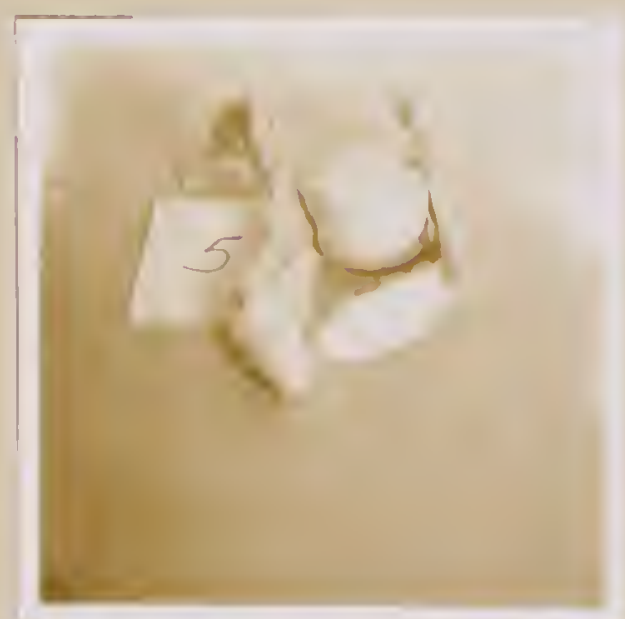

Figure 4. Forelers of young rabbit showine shiftod camus joint. $-1 n$ 
manifestations were completely corrected. The strenth of the legs appeared to improve and in the case of one rabbit in which the left leg was not severely affected, it returned to its nornal position. The lower photorraph of rabhit muber 385 in Finure 2 shows the partial recovery following copper thcrapy. The bone injury appears to be permanent. In attempting to relate this condition to that due to a manganese deficiency, it would be desirable to know whether or not the crookedness in manganese deficient rabbits can be corrected with manganese therapy or wether the injury is pemanent.

Two of the characteristic symptoms of molybdemun toxicity in cattle, namely diarrhea and a change in color of the hair coat, have been consistently absent in the syndrome observed in rabbits. In view of the marked alopecia occurrine in some animals it is possible that achromotricia may have been masked. It should be observed, however, that achromotricia was not present in those rabbits wich :ere receiving hich levels of molybdenum but which did not develop alopecia. 


\section{EXPERTENTT II}

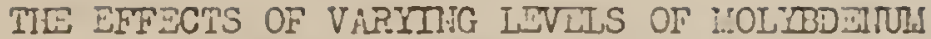

UPOI, THE GROITH OF RABBITS

Common amone the symptoms of molybdemm toxicity in species which are subject to the toxic effects is retarded groutin or a decrease in body weicht. Retarded growth has been observed in rats even though other gross abnormalities were not present. The study of the action of molytodemm upon the frowth of young animals is desirable, therefore, in evaluating the effects of sub-lethal quantities of this toxic element. luch of the grorth data reported relative to the effects of molybdem have not been accompanied by adequate feed consumption data so it is difficult to detemine whether or not molybdemm per se is the cause of sub-normal growth. The recent experiments of jeter (49), however, indicate that the retarded grorth of rats cannot be attributed to a decreased food intake.

This experiment was desimed to detemine the relative rates of rrovth of reanling rabbits fed varyinf, levels of molybdemon.

\section{Boperinental Procedure}

Twenty-four weanling Dutch rabbits from cight litters were randomized into five treatments consisting of a basal ration and four levels of molytudem added to the basal ration. The rabbits were six to seven mecks of are and weighed 585 to 820 rrams.

The basal ration was the same comercial pellet ration used in Experiment I. The levels of molybdenum added were $0.114,0.05,0.1$ and 0.2 per cent of the ration, added as sodiun molybdate. Rabbits 
were housed and managed under the same conditions as outlined in Doperiment $I$.

Growth was deterninod from weckly weirhts made throughout the fourteen weel: growth period. Feed intake measurements frere made periodically during the experimental period.

\section{Results and Discussion}

The mean weekly weights of the rabbits on the different levels of molybdemm are shown in Table 2. Nolybdenum at the level of 0.1 per cent and higher retarded grouth. Belor this level there was no effect upon the rate of gain. A test of significance for the difference in the amount of gain at tirelve weeks for the control croup and the group receiving 0.1 per cent molybdemum showed no statistical significance (P2.05). At the higher levels of molyodemum, grouth was greatly restricted and most of the animals died bcfore a reasonable Erowth period was comploted.

Iinited observations show that the rabbits on the hifher levels of molybdemm consuned less feed. The intake was not materially reduced, horrever, until symptoms of the toxicity appeared. There is no evidence that the molybdemu rations were unacceptablo, for during the carly weeks of the experiment, intakes were essentially normal. Ifter some reeks on the experiment, rabbits receiving the toxic lovels of molybdemm wore observed to plck over the pellets and to scratch wildly in the feed cups.

Then the effects of molybdenum upon the groith of the rabbits are cormared rith the action of molybdemm in causing anemia, alopecia 


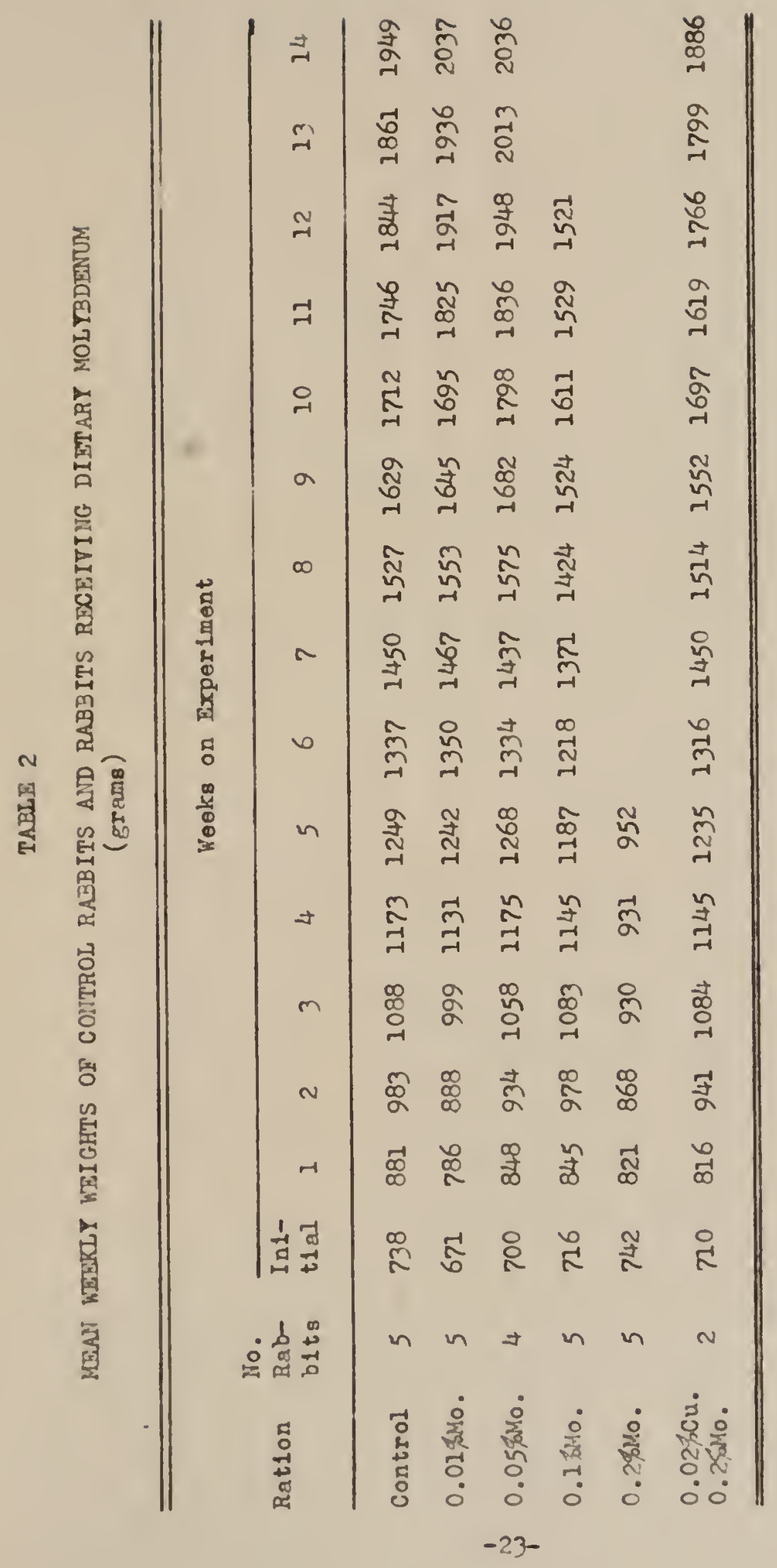


and other toxic symptoms, it can be observed that moith was retarded only in those animals wich developed the toricity syndrone. Then the toxic symptoms were absent, even though the rabbits were receiving molybdemu, growth was not retarded. This observation is in contrast with the effect of molybdemm upon rats where grorth has been retarded in the absence of other gross abnormalities.

In evaluating the effects of molybdenum in this experiment, it is necessary to consider the relatively high level of copper (15.4 ppm) in the basal ration. With this intalee of copper a greater tolerance for nolybdemm would be expected. The action of molybdemun in retarding Erowth is, however, demonstrated. Since the consumption of feed was somewhat less in the Eroups in wich growth was sub-normal, it cannot be deternined whether or not molybdemum per se retards growth or reduces the feed intake. 


\section{EXPGRDIUT III}

\section{THE LFTECTS OF VAPIIITG IIIVILS OF LOLIBDEMII}

UPOII TIE HE:OGLOBIH, RED BLOOD CELI COUIT

AID BLOOD VOLU.ES OF RABBITS

Anemia is comon in the syndrome of molybdenum toxicity in cattle and sheen. The investigations wich have related anemia to excess molybdemum have not included intensive studies relative to other chances in the blood picture. Included in this experiment are observations of the changes in hemoglobin, red blood cell count and blood volume of normal rabbits and of rabbits suffering from molybdemm toxicity.

\section{Ixperimental Procedure}

Blood analyses were made on the rabbits in Experiments I and

II. The analyses were made concurrently vith the development of the toxic symdrome and with the observations upon the growth of the rabbits. lio alterations were made in the feeding or manacement pro codure.

Blood samples were taken from the marginal ear vein and hemoglobin determined every two weeks on the exoerimental animals using the acid hematin method (20). ":hen the first symptoms of toxicity appeared, determinations rere made more often in order to follow nore closely tho changes in homoglobin.

Red blood cell counts were made on the blood from representative control rabbits and those receiving hich levels of molybdemm before and after the homoplobin beran to dccrease. Cells were counted 
in the standard red cell counting chamber after dilution in Hayan's solution.

The blood volune of tiro control rabbits and of six rabbits receiving varying levels of dietary moljbdemm was determined. The determinations were made with phosphoms ${ }^{32}$ labelled cells $(45)$ and also by the dye dilution method $(4,62)$. The rabbits were given ether anacsthesia and both jugular veins rere exposed. Injections and withdratrals were made from opposite veins and the calculations based upon samples of blood taken after five and ten mimute intervals.

\section{Results and Discussion}

The mean hemoglobin values winich were obtained from rabbits on the control ration and the different levels of molybdemu are prescnted in Table 3. These averages do not represent values from all rabbits in each group, but are calculated from determinations made on three to five rabbits in each treatment which were representative of the groun. The values obtained for the control rabbits and those receiving the lower intakes of molybdenum $(0.014$ and 0.05 per cent) were within the normal range for this species (23). The rabbits receiving 0.1 per cent or more molybdemum in the ration developed anemia as cridenced by the lor heroplobin. Sinco the values reported in Table 3 are averapes, the extrencly low hemoglobin which was found in some animals is not evident. In Table 4 are show the hemoglobin values for some individual rabbits as anemia developed. Anemia ras first observed at about tho samo timo that other symintoms of toxicity became evident and the hemorlouin contimod to decroaso 
until death occurred or until copper therapy was initiated. Henoglobin as loiv as 2.0 grams per $100 \mathrm{ml}$ blood has been observed before death occurred.

The number of erythrocytes in the blood of normal rabbits and experimental rabbits before the toxic symdrome developed were vithin the noinal range for rabbits (23). Then anemia appeared and progressed, there was a corresponding, decrease in the red blood cell count. In Table 5 are henoclobin values and red blood cell counts of some individual rabbits. These data relate the hemoglobin measurements to the number of erythrocytes and further relate the anemia to dietary molybdenum.

TABLE 3

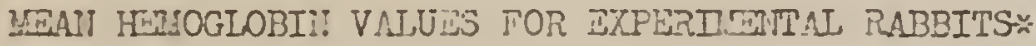

iioek on

Per cent molybdenum in ration

Sxperiment

Basal

0.014

0.05

0.1

0.2

Initial

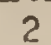

4

6

8

10

12

14

16

18

12.5
12.9
13.0
12.8
13.8
12.1
12.9
$13 . ?$
11.0
12.4

12.1

12.6

11.3

11.3

1?. 1

13.3

13.9

16.2
12. 1

1. 3

12.8

1.9

12.5

12.1

12.6

13.0

1):. 3

16.2
1.6

13.2

3.6

7.6

11.8

23.3

10.?

7.3

5.7

* Grams hemoglubin per $100 \mathrm{ml}$ blood.

… Values not determinod. 


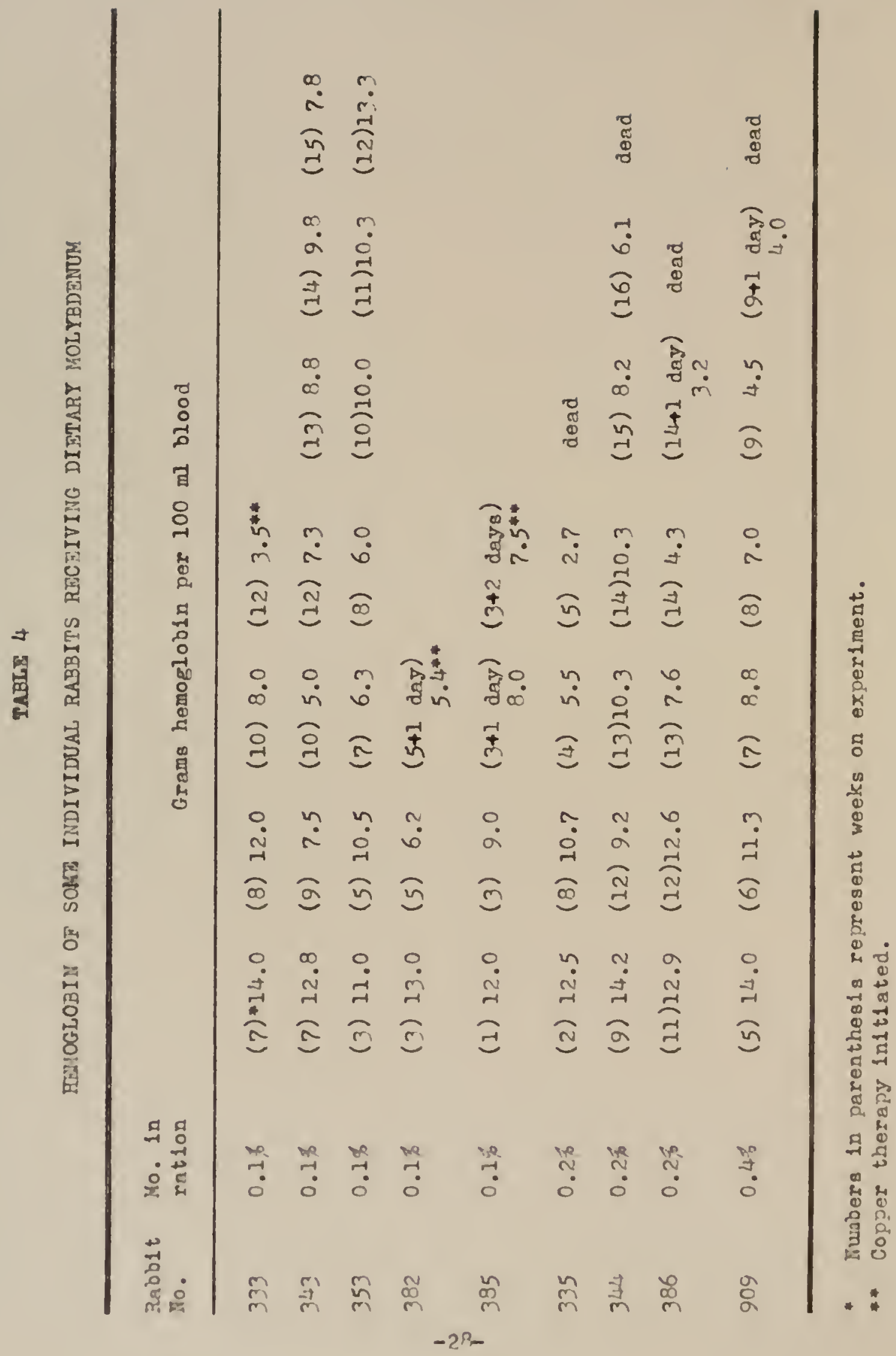


T.BILE 5

HESOGLOBII AD RWD BLOOD CEIL COUTSS OF IIDIVIDUAL IRLBBITS

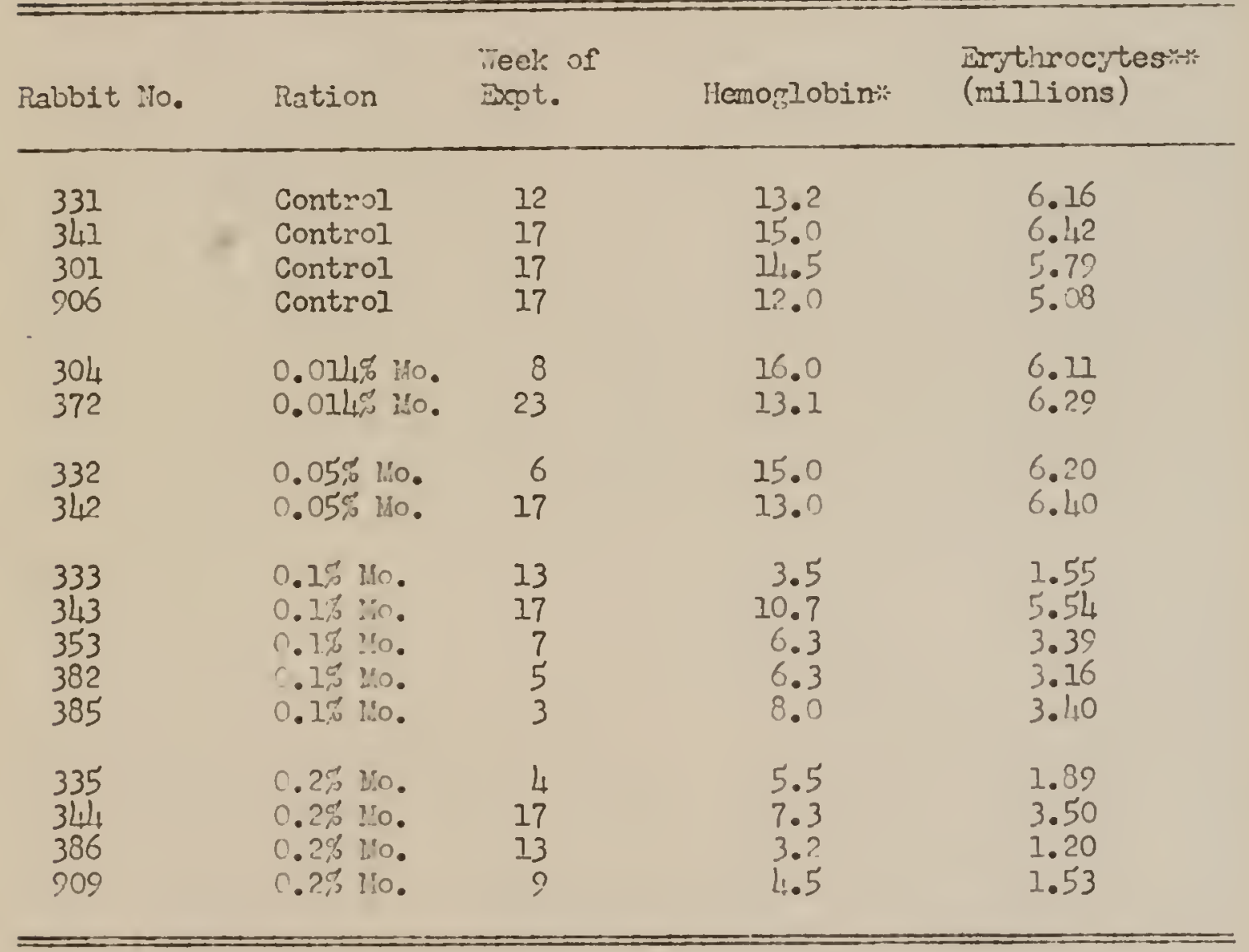

* Grams per $100 \mathrm{ml}$ Blood.

苾 Cells per cubic millimeter. 
Limited measurements of the red blood cell size indicated that erythrocytes were snaller and more variable in size in anemic rabbits than in normal rabbits.

The blood volume for the control rabbits and experinental rabbits is recorded in Table 6. Other data relative to the blood picture wich were obtained at the same time are also presented. The relationship of the plasma volume to the red cell count is also reflected in the lom homorlobin and red cell count. The blood volune of all of the rabbits is within the normal range for the are and reight of the aninal. It is simificant that blood volume was maintained at a normal level even though severe anemia was present. The results indicate, therefore, that the mechanism for maintainine blood volume is not affected in molybdemu toxicity. 


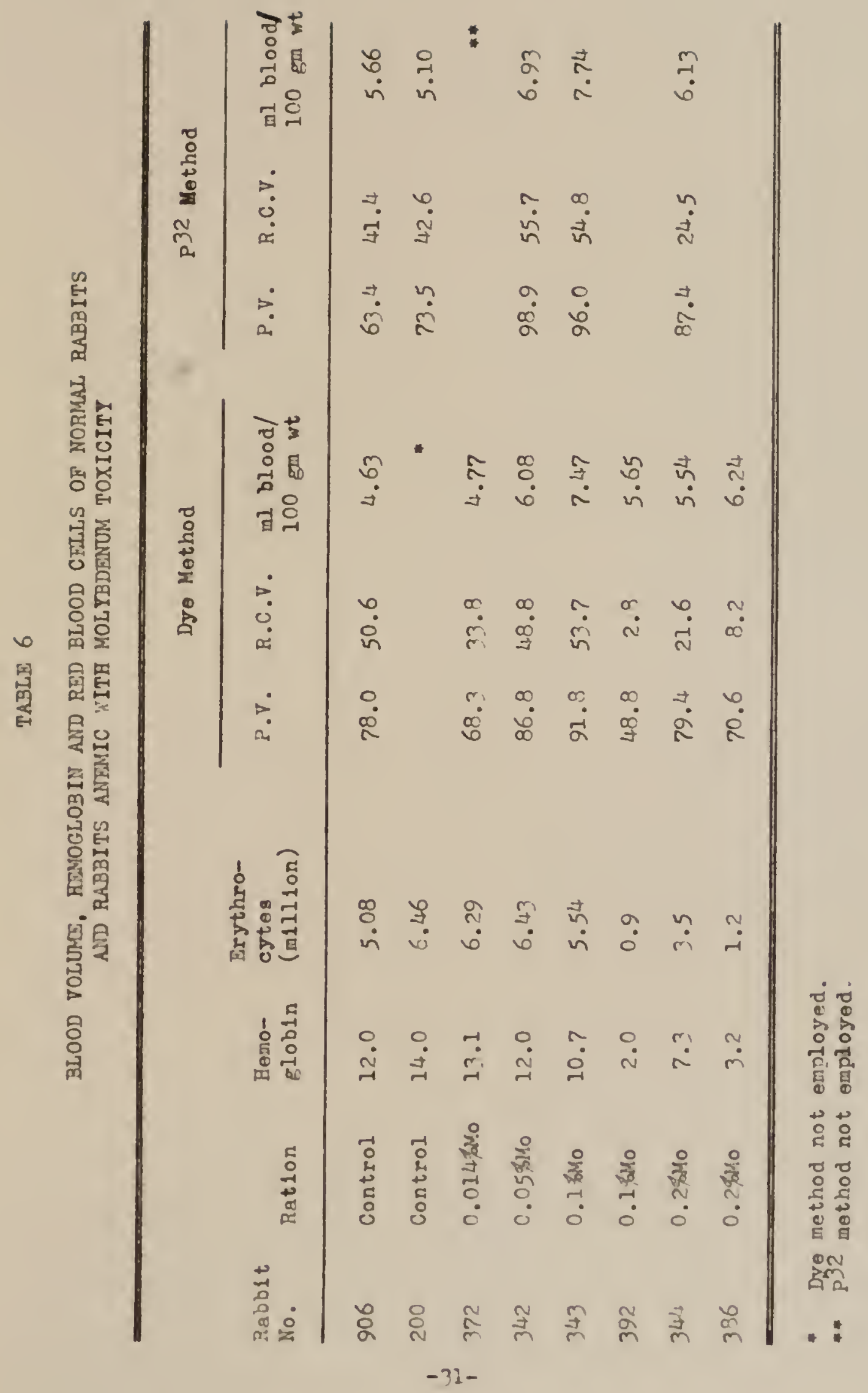


In considering the role of molyodemu in animal mutrition, it is now evident that its offects must be related to the copper intake and copper status of the animal. The therapeutic action of copper upon the copper status of the animal has already been revieved. Included in this experiment are observations on the prevention of molybdenum toxicity with dietary copyer, the therapeutic action of copper, and the relation of molybdemu to liver storage of copper in the rabbit.

\section{Meperinental Frocodure}

Tro meanling Dutch rabbits, six to seven weeks of are and weiching 628 and 791 grams, were placed on a ration containins .02\% copper and $0.2 \%$ molytodemun. The basal ration was the cormercial rabbit pellets used in prior experiments. Feeding; and manacement procedures were the same as previously outlinecl. Daily obscrvations were made for appearance of any abnormalitics and body weichts rade weokly for prorth estimation. Copper as $\mathrm{CuSO}_{4} \cdot \mathrm{5H}_{2} \mathrm{O}$ and molybdenura as 11 alo $\mathrm{O}_{4} \cdot 2 \mathrm{H}_{2} \mathrm{O}$ were sprayed onto the ration from aqueous solutions. It was necessary to add each of the salts to separate portions of the ration then mix after dminr.

In ordor to furtice observe the therapeutic effoct of conner, three rabblts wich were receivin hich levols of nolyodenum and had devolopod the typical toxicity syncromo mere trantod with copper. The 
clinical manifestations rere alloned to progress until it appeared that the animals would not longer survive without treatment. it this time thej rere given a drenc's of $0.05 \mathrm{gm} \mathrm{CuSO}_{4} \cdot 5 \mathrm{H}_{2} \mathrm{O}$ in $10 \mathrm{ml}$ water and thereafter they were supplied drinkin, water which contained 0.1 cm $\mathrm{CuSq}_{4} \cdot 5 \mathrm{H}_{2} \mathrm{O}$ per $500 \mathrm{ml}$ water. Clinical observations were contimed in order to follow the changes resulting fron copper treatment.

At the termination of the experiment, rabbits were killed or sacrificed for phosphorus balance and distribution studies. Livers and femur bones were removed and copper storage in the liver detemined using the carbamate method (66).

\section{Results and Discussion}

lieither of the rabbits which was fiven supplementary copper and molybdemm in the ration developed any of the symptoms of nolybdemm toxicity. The rate of gain was slirhtly less but not sicnificantly lower than the control rabbits (Table 2). The level of molybdemm in this ration $\left(0.2 \%^{\prime}\right)$ had proved to be toxic in the absence of added copper so the protection afforded by the copper is domonstrated.

From other observations made in this phase of the experinent, an estination of the ratio of copper required for protoction may be mado. When the copper sulfate solution was added to the ration, this portion turned distinctly blue-rreen in color so that evon istien mixed with the nomal colored molyidemm treated portion, the copper pellets were casily distinguishable. The rabbits picked over the ration, leaving a larpe portion of the copper treated pellets. Because of the 
difference in cclor, it could be observed that much less than the calculated anount of added copper mas actually consumed. Therefore, the amount of copper required to protect against the $0 . ?$ per cent molibdenum was much less than 0.02 per cent added copper and more than the 0.0016 per cent contained in the basal ration.

The three rabbits which had severe symptoms of toxicity and were treated irith copper responded rapidy to the copper therapy. In Table 7 data are presented illustratine some of the changes which were observed folloring the initiation of copper treatment.

ilot show in the table are the effects of the treatment upon alopecia and dematosis. Dernatosis disappeared and the hair began to return to the demded areas within about a week.

The return to normal weight gains, normal hemoglobin and full hair coat was renerally complete within one month. There was only slipht improment in the forclef, abnomality after five months treatment ith copper. The failure of this condition to respond to copper has been discussed in Experinent I.

The relative accurulation of copper in the livers of rabbits on the different dietary levels of molybiemm is shom in Table 8. The hipher concentrations of copper in the livers from those rabbits which received supplementary nolybdemm shoir that molybdenum had a teniency to cause an increase rather than a docroase in the copper storape. The concentration of copper in the livers from those rabbits recolvine, supplenental moljtudomm and copper wo considerably hicher than that fouml in any of the nther proups. This intalio of copner 


\section{TABI.E 7}

WFECTS OF COPPER MTLRAFY UTON "TEIGIT, HMOGLOBIN LEVEL, MDD

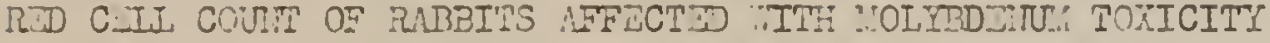

\begin{tabular}{|c|c|c|c|c|}
\hline $\begin{array}{l}\text { Rabbit } \\
\text { Mo. }\end{array}$ & $\begin{array}{l}\text { Time after } \\
\text { treatment }\end{array}$ & "reicht & Hemorlobin & \\
\hline 333 & $\begin{array}{l}\text { Initial } \\
1 \text { week } \\
2 \text { wecks } \\
3 \text { weeks } \\
5 \text { wecks }\end{array}$ & $\begin{array}{l}1144 \\
1737 \\
1204 \\
1362 \\
1148\end{array}$ & $\begin{array}{r}3.5 \\
7.0 \\
10.0 \\
10.8 \\
12.5\end{array}$ & \\
\hline \multirow[t]{2}{*}{382} & $\begin{array}{l}\text { Initial } \\
1 \text { meeli } \\
3 \text { mecks } \\
5 \text { weeks }\end{array}$ & $\begin{array}{r}853 \\
015 \\
1030 \\
1276\end{array}$ & $\begin{array}{r}5.4: \\
2.0 \\
12.7 \\
13.0\end{array}$ & \\
\hline & & & & $\begin{array}{l}\text { Frothrocites } \\
\text { (millions) }\end{array}$ \\
\hline 385 & $\begin{array}{l}\text { Initial } \\
1 \text { day } \\
3 \text { days } \\
\text { I week } \\
\text { ? weeks } \\
\text { I! weeks }\end{array}$ & $\begin{array}{r}907 \\
871 \\
941 \\
993 \\
1296\end{array}$ & $\begin{array}{r}7.5 \\
8.0 \\
7.5 \\
10.5 \\
11.0 \\
10.3\end{array}$ & $\begin{array}{l}3.75 \\
4.15 \\
3.80 \\
1.69\end{array}$ \\
\hline
\end{tabular}


was not considered a high level but was estimated to be the amount necessary to prevent the toxic action of molybiemum. The quantity of copper found in the livers of the control rabbits is slichtiy greater than the amount reported by Lorenzen and Snith (54) and is considerably higher than the quantity reported by Cunninghan (24). Although the liver copper was not greatly increased except in the group receivins supplemental copper, it is significant that molybdemum did not cause a decrease in the copper content of the liver. This finding supports previous observations (51,58) that molybdenur. tends to cause an accumulation of copper when the intake of copper is adequate.

\section{TABLE 8}

ACCURULATIOH OF COFPER III LIVERS OF ECPERIIFMTI RABBITS OII DIFTEDETT I:OLVBDEITI AID COPFUR INTINES

\begin{tabular}{|c|c|c|}
\hline Pation & $\begin{array}{l}\text { llo of } \\
\text { Rabbits }\end{array}$ & $\begin{array}{l}\text { licrograms cu per } \\
\text { Eram dry liver } \\
\text { (average) }\end{array}$ \\
\hline Control & 5 & 29.7 \\
\hline C.011,\% lio. & 5 & 30.2 \\
\hline $0.05 \%$ Vo. & 3 & 45.0 \\
\hline $0.1 \% \mathrm{l!o}$ & 5 & 35.7 \\
\hline $\begin{array}{l}\text { ก.2\% :0. } \\
\text { ก.02\% Cu. }\end{array}$ & 4 & 60.5 \\
\hline
\end{tabular}




\section{EXPEPIRAT V}

\section{TIE BFFECTS OF LOH IMTAFES OF DIJTARY I'OLYBDEIU! AD OF VITAITIS A ND E IV TIESE DIETS UEOH THE GRO:TH AID RERODUCTION OF RATS}

The results from several investigations of the role of nolybiemm in the rat show that the elment is toxic, causing death at high levels and retarded groith at sub-lethal levels. Previous work in this laboratory has shorm that 30 and $\nu_{1} 0 \mathrm{ppm}$ moljodomm in a simplified ration simificantly retards growth. Observed also in this experiment was an interference with reproduction (4?). From these tro observations it appearcd that there mirht be a deficiency of vitarin $A$ or vitamin $\mathrm{E}$ as a result of the action of molvbdenum. If the vitamins become deficient by being tied up in the alimentary tract, or are otherwise rendered ineffective by molybdemm, the deficiency should be corrected by therapeutic administration of the Vitamins. This experiment was desinned to further study the effects of low intakes of molybdenum upon groith and reproduction of rats and to study the effects of vitamins $A$ and $\Xi$ added to diets containine molybdemus.

\section{Enertmental Procedure}

Ilinety weanline rats of the Sherman strain, 21 to 23 days old, were randomized into three treatrents of 30 rats each. These treatments consisted of the basal ration and two levels of rolybdenur $(0.014$ and 0.02 per cont) added to the basal ration. These three treatments rere further subdivided into three sub-rroups of 10 rats 
each approximately equally distributed between nales and females. One of the sub-groups in each treatment was considered the basal treatment for the addition of the vitmin $A$ or vitarin $\Sigma$ to each of the other two sub-groups.

The rats were housed in metal wire cages naintained in an airconditioned room at $80^{\circ} \mathrm{F}$. Rations were fed ad libitum and pyrexdistilled water was provided fron glass ratcring bottles.

The composition of the basal ration is recorded in Table?. The whole mill: powder was Powdered Kim, received in vacuum packed containers. Pations were prepared fresh about each ten days. The copper content of this ration was 5 ppr. Vitamins $\Lambda$ and $E$ trere adrinistered directly to the rats with the use of a medicine dropper. The vitamins rere given trice weekly in amounts that supplied 5,000 units of vitamin A and 12 milliprams of alpha tocopherol in each dose. Vitamin $A$ was in the form of a natural ester concentrate and vitamin $\Sigma$ was alpha tocopherol acetate.

Groith was determined from weckly weirhts made throughout the twelve wreek groith period. At 16 weeks of age females were bred to males on the same ration and any rats wich did not breed were later exposed to other rats to checl: the cause of the breeding failure.

In order to observe the protective action of cop"er acainst the effects of molybdemu, one ration was prepared which contained $0.02 \%$ molydenum and $0.102 \%$ copper. The basal ration for the trial was the sane as previously used. The composition of both is show in Table?. Five male and fnur female weanline rats woro used in this 
trial and procedures previously outlined mere usod for obtaining data. These rats rere not piven vitamins.

\section{TABIE ?}

CarFOSITIOI OT RATIONS

(errans)

\begin{tabular}{|c|c|c|c|c|}
\hline 4 & Basal & $\begin{array}{l}\text { Basal + } \\
0.014,010 .\end{array}$ & $\begin{array}{l}\text { B.sal + } \\
0.02 \% \text { Mo }\end{array}$ & $\begin{array}{l}\text { Basal + } \\
0.002 \% \text { Cu } \\
0.02 \% \text { ilo }\end{array}$ \\
\hline \multicolumn{5}{|l|}{ "hole ililk } \\
\hline Forder (17im) & 3415.0 & 3415.0 & 3475.0 & 34.15 .0 \\
\hline Sucrose & $3380 . ?$ & 3380.0 & 3380.7 & $3380 . ?$ \\
\hline IVaCI & $3 \mathrm{li.})$ & 34.0 & 34.0 & 34.0 \\
\hline $\mathrm{FeSO} \cdot 7 \mathrm{H}_{2} \mathrm{O}$ & 16.0 & 4.? & $4 . ?$ & 4.0 \\
\hline $\operatorname{linSO} \cdot \ln 0$ & 2.52 & $\therefore 52$ & $? .52$ & $\therefore 52$ \\
\hline Thiamine hydrochloride & 0.023 & 1.023 & 0.023 & 0.223 \\
\hline Fyridoxine hydrochloride & 0.033 & 0.033 & 0.733 & ก.033 \\
\hline $\mathrm{CuSO}_{4} \cdot 5 \mathrm{H}_{2} \mathrm{O}$ & $\cap .20$ & 0.10 & 0.10 & 0.528 \\
\hline iailoO $\vec{q}_{4} \cdot 2 \mathrm{H}_{2} \mathrm{O}$ & 0.0 & 2.38 & 3.143 & 3.43 \\
\hline
\end{tabular}

\section{Results and Discussion}

The mean weelly weights of the rats throughout the 1 weel groith period are recorded in Tables 10 and 11 . Vieights of the male rats are found in Table 10 and females in Table 11. Nso included in the table are the averace total gains for each group. The growth of the male rats receiving molytolomm was significantly less than the frowth of those in the basal group. The difference in the amount of pain for the rroup receiving. $0.01 /$ per cent molyudemu and of the basal group was hichly sicnificant $(\mathrm{P}<01)$. For those recciving 0.02 per cent molyodemn, the gain was sirnificantly less (PC.05). 


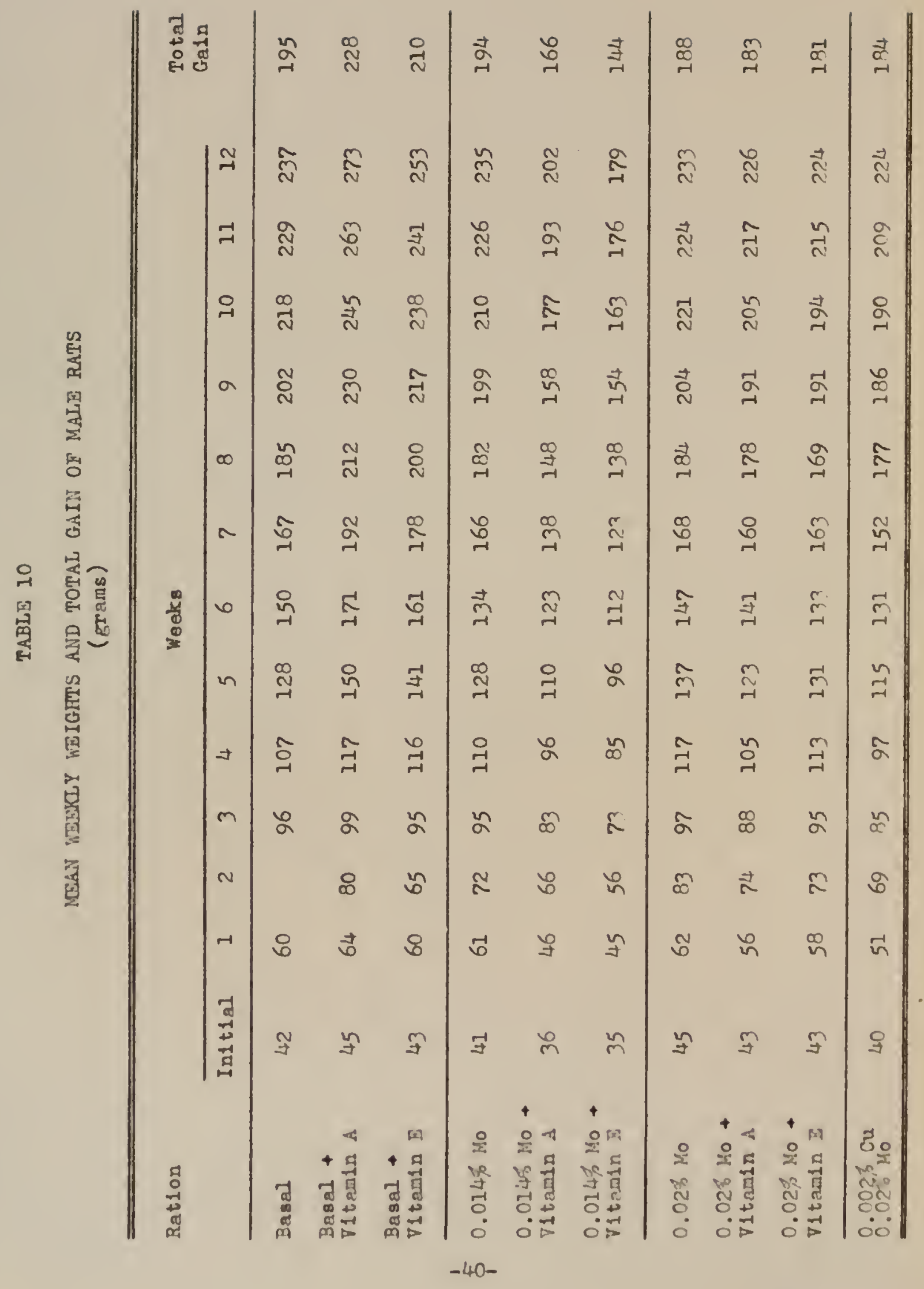




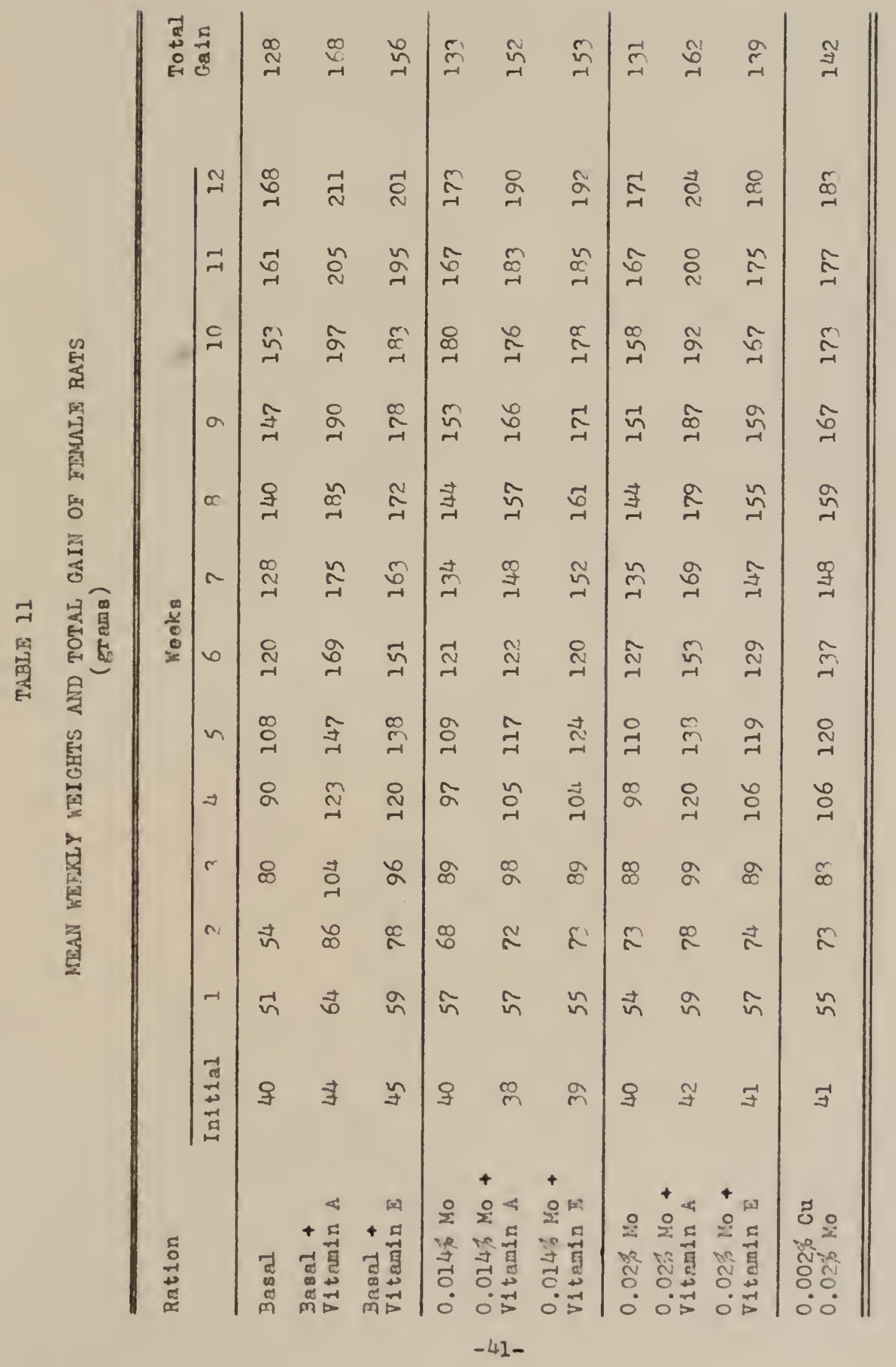


The crouth of the female rats receiving nolybdemun appeared to be retarled, but the differences in amount of gain vere not statistically signiflcant for either level of nolyudemm. This scx difference in response to molybdemen supports a previous observation (4\%) that male rats are less tolerant to dietary molybdenum than are female rats. The offects of the vitamins may also be observed in Tables 10 and 11. The addition of both vitamins $A$ and $E$ increased the grorth of female rats on all treatnents including the basal ration. No consistent differences in the growth of male rats could be attributed to either vitamin. The objective of the vitamin supplementation was to study its possible therapeutic effect upon molybdenum toxicity. Although both vitamins appeared to increase the groith of the fenale rats on both levels of molybdemu, they had a like effect upon the females on the basal ration; therefore, the relation to molyodemum could not be observed. In the male rats where the adverse effects of molybdenum were more evident, it should be obscrved that neither vitamin A nor vitamin $E$ increased the grouth. From this obscrvation It apnears, therefore, that neither vitarin $A$ or vitarin $\mathbb{E}$ is effective in counteracting molybdenum toxicity.

The average reekly woiphts and total gain of the rats given 0.002 per cent copper and 0.02 per cent molybdenum are recorded in Tables 10 and 11. This amount of copper was not considerod a high level of diotary copper but was the quantity ostinated to be necossary to counteract the offects of molydiemun. This ration, however, did not support prowth in tho malo rats oqual to that of the controls. The 
amount of gain was simificantly less than the cains produced in control male rats. There was no significant difference in the grouth of these fomalc rats. The grouth of these fomales which was approxinately equal to that of the control fenales cannot be attributed to the presence of the additional copper since the female rats thich received molybdenum but without the additional cop: cr made approximately equal gains.

The results of the breeding trials are sumarized in Table lî.

TABLE 12

FEPTILITY OF WLE NID FDLLE RATS RECBIVIIG

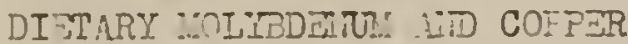

Tation Vales Females

\begin{tabular}{|c|c|c|c|c|}
\hline $\begin{array}{l}\text { :o. } \\
\text { :atings }\end{array}$ & $\begin{array}{l}\text { Ilo. } \\
\text { Iitters }\end{array}$ & $\begin{array}{l}\text { io. } \\
\text { Sterile } \\
\text { liales }\end{array}$ & $\begin{array}{l}\text { lio. } \\
\text { latines }\end{array}$ & $\begin{array}{l}\text { No. } \\
\text { Litters }\end{array}$ \\
\hline
\end{tabular}

\begin{tabular}{|c|c|c|c|c|c|}
\hline \multirow{2}{*}{ 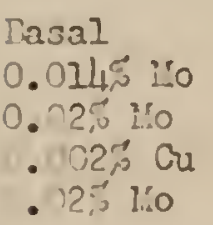 } & $\begin{array}{l}6 \\
6 \\
5\end{array}$ & $\begin{array}{l}6 \\
6 \\
4\end{array}$ & $\begin{array}{l}0 \\
0 \\
1\end{array}$ & $\begin{array}{l}5 \\
4 \\
5\end{array}$ & $\begin{array}{l}5 \\
4 \\
5\end{array}$ \\
\hline & 5 & 5 & 0 & 4 & t \\
\hline
\end{tabular}

Fro: these results, no simificant effect of the anount of nolybdemur: fed can be observer. The proportion of fertile rats in the moups receivinf, supplemental vitamins $A$ and $\bar{z}$ mas the same. Since the molybdemm did not produce sterility in this experiment, the effects of the vitamins unon reproduction cannot be determined. These results arc contrary to the results of fertility excriments vith rats (l:9). 
therein a large proportion of male rats on a similar dietary regime were sterile. A higher level of molybdenum has been fed in the current experiment vithout causing sterility. The basal rations and other conditions of these two experiments were similar; however, the following changes applied to the current experiment may account for the differences in results: (1) Sherman (albino) rats vere used in this exporinent. The Long-zvans strain was used in the former experiment. (2) The iron and manganose content of tire ration was increased. (3) Pyridoxine was added to the ration. These changes apparently improved the ration, as reflected in somewhat better growth of the animals, and irith an improved mutritional status of the animals, the greater tolerance to molybdenum rould be expected.

During the course of the experiment, a peculiar alopecia was observed in some of the male rats receiving nolyodemu and also in those receiving the hicher level of copper with molybdenum. It ras not present in all of the rats of any group nor was the loss of hair pemanent. This alopecia was much more comon in the male rats and was limited to a strip approxinately an inch wide ovor the entire leneth of the back. Finure 5 silows pictures of typical rats exhibitine this alopecia. Alopecia appeared in some of the other rats, particularly about the neck and shoulders, but it was not confined to the rats receivine molybdomu, nor was it observed more in male rats than in females.

The alopecin which occurrod ovor the back of the antmals appoared to bo associated with molvbdonum. Mlthough loss than ono-third 
of the male rats on the molybdem diets exhibited this particulas tipe of alopecia, none of the rats of the basal group were so affected. Iopecia has been observed in rats on similar diets, but it was nore characteristic of the female rits than of males (49).
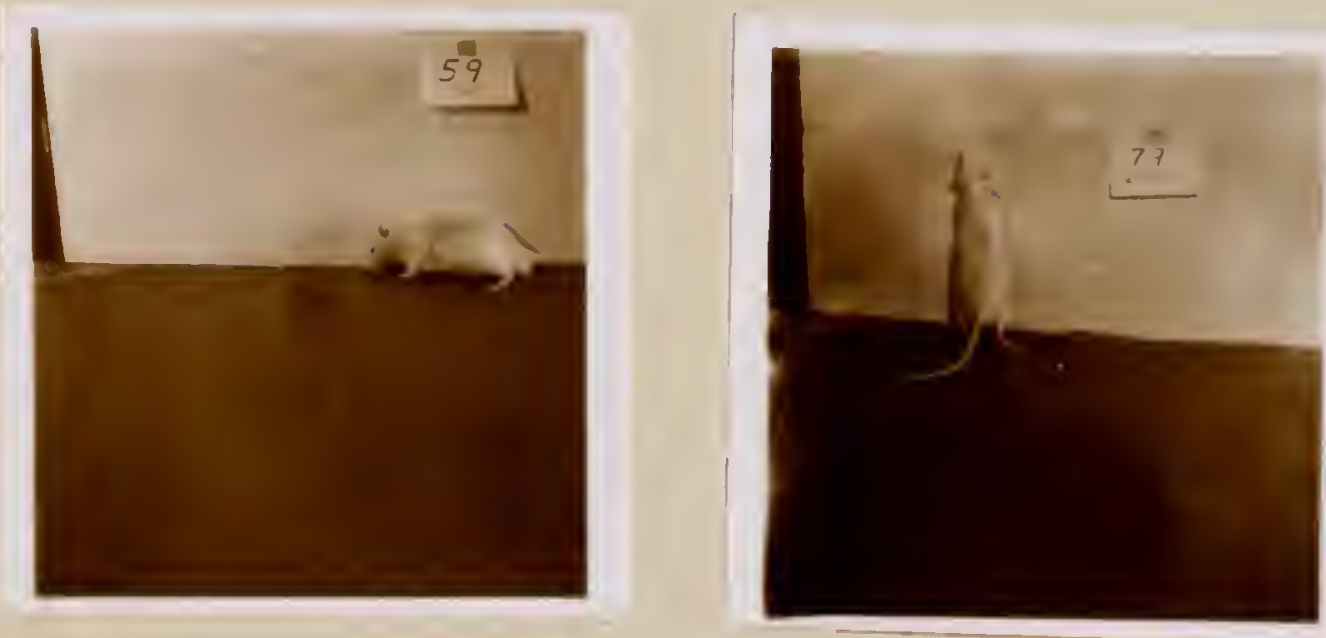

Finure 5. In.te rats on molybdenum diets exhibitine, alopecia over the back. 


\section{EXPERTIEIT VI \\ PHOSPHORUS IETABOI,ISI AND DISTRIBUTIOH OF \\ PHOSPHORUS32 II! THE RABBIT AID RAT}

Certain abnomalities in skeletal formation have been attributed to excess molybdemm in the dietary. Some of the investigations wich have been undertaken to relate this abnomality to molybdemu have demonstrated an abnormal phosphomus metabolism when molybdemu was in excess. The observation made early in this experiment that the front legs of some young rabbits develop abnormally when fed high levels of molybdemum demonstrated that nolybdemum interferes in some manner with nomel skeletal development in this species. In the absence of other explanation, it appeared possible that there was an interference with phosphoms metabolism.

This experiment was undertaken to obtain data which would afford an evaluation of phosphorus balance in normal rabbits and rats and in rabbits and rats wich were receivine dietary molybdemu. Also included in the study are observations on the distribution of radio active phosphorus in these animals.

\section{Ixperimental Procedure}

The aninals usod in this study were selected from those used in previnus experiments. They were contimod on the same ration after completion of the growth studies. Four young rabbits and 18 younf rats were introduced into the experiment at this time in order to obtain data from younr, animals.

Fhosphorus balanco studios wero made usinf. radioactivo phosphorus 3 ? 
Follorine adzinistration of the isotope, rabbits werc confined for 72 hours to metabolism caces mich rovided quantitative scparation of urine and feces. Tise $7^{2}$ h vr period r:as sclected beciuse preliminary ouservations indicated that the rreater portion of the is?tope ins excreted rithin this time. Ten rabbits rere riven oral adninistration of the isotope and seven vere riven intravenous injections through the marrinal ear vein. idministration to the rats iras nade orally and collection periods were 49 and 72 hours.

At the end of the metabolism period, the aninals rere sacrificed and selected tissies talen for distribution studies. Urine and feces were collected and the radioactivity deteminod on roprescrtative samles.

The radioactive phosphorus which "ras recoived in the frrm of Fhosphoric acid was neutralized with sodiun carbenate and made isotonic with sodium chloride prior to administration. The dosare administered to rabuits ranged from 1.5 to 5 microcuries and tile rats :"cre civen 1. to 2 microcurics.

Padiozctivity measurements rere made in tive usual manner using. a reifer-ivler counter fitted : ith a dipning tube. Urine and blood sarples were counted dircetiy without ashin. Eefore determinine the activity of the abbit urine, it was necessum to acidify the urine rith hyirochloric acicl in order to dissolve the solid portion of the urine. This portion was obscrved to contain a 7arec nroportion of the phosphorus and unless it wne dissolved or thorouphly suspended, the measurements werc inaccurate. Feces and tissue samples vere ret 
digested with nitric acid and heat prior to activity measurements.

Calculations mere made of the por cent of total dose excreted in tine urine and feces during the balance period. The per cent of total dose per fran of tissue was detemined for the liver, lidney, femur, muscle and blood and the per cent of dose was corrected to the averace body rei ht of the animals.

The total phosphorus content of femur bones and certain other tissues was determined using a modification of the volumetric method outlined in lethods of Mnaiysis of the Association of Official Mgricultural Chemists (6).

\section{Results and Discussion}

Balance Studies - The data representing the balance studies with rabbits are sumarized in Table 13. The values reported are mean values for the per cont of total dose winicin was excreted in 72 hours by way of the urine and the feces. Results are piven for both oral and intravenous administration of the isotope. The results show that a reater proportion of the orally administered phosphorus 32 was excreted by the rabbits which were receivine dietary molybdemum. There was a significant increase in both urinary and fecal excretion of the labeled phosphorus. Follorrine intravenous administration, there was no observed differonce in the total amount excreted nor in the pathway of excretinn. This indicates that in the rabbit nolybdenum did not alter the pathway of excretion as has been observed in steers (63). On the hich molydemum rations, the urinay excretion of total phosphorus incroaser almost fourfold wilc fecal excretion of total 


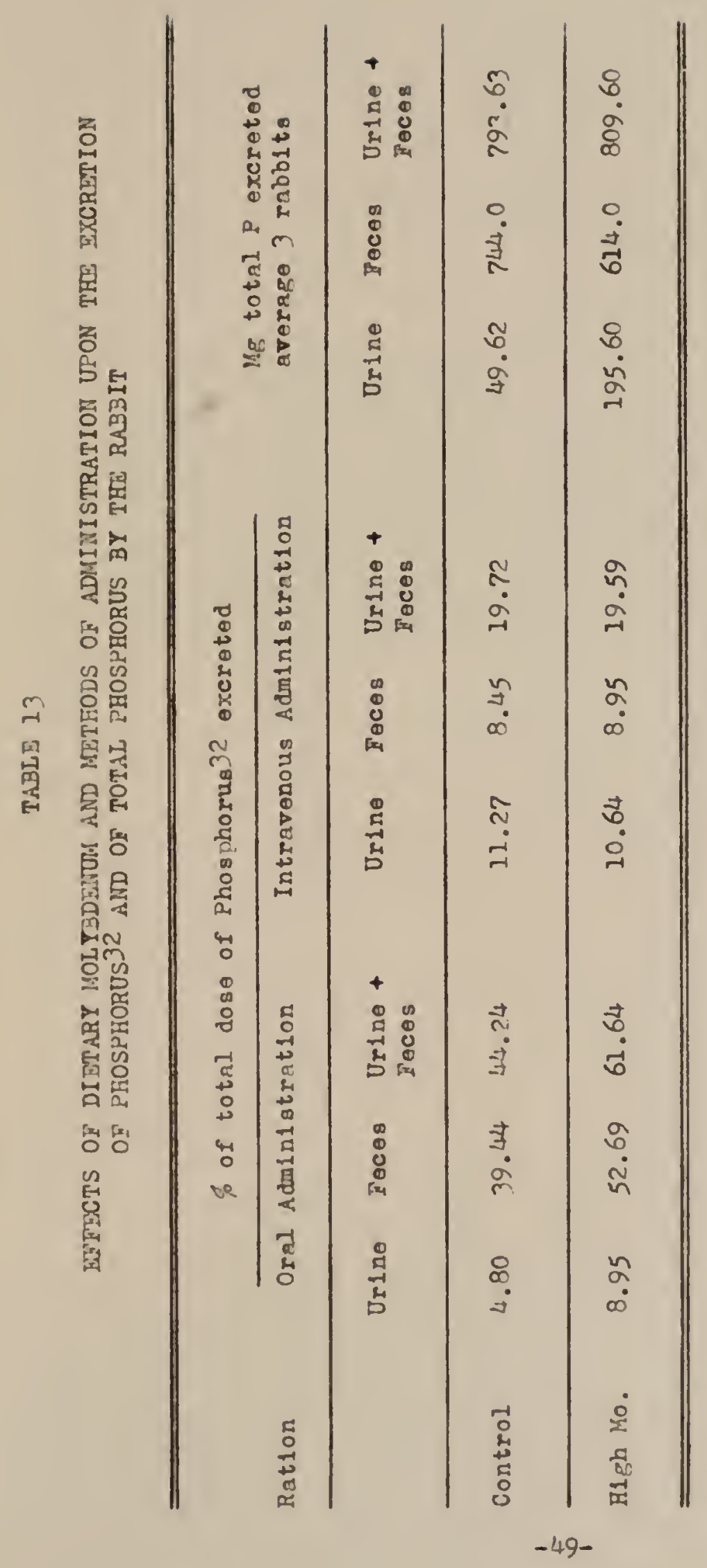


phosphorus was not significantly affected. The increased excretion of both labeled and total phosphorus by way of the urine in animals on liigh molybdemu diets indicates that molybdenum may decrease the absorption of phosphoms and at the sane tine increase the excretion of that wich has been absorbed. Since there was no sifnificant alteration in the excretion of labeled phosphorus following intravenous adrinistration, it appears that tile prinary effect of nolyto denum is in the gastro-intestinal tract.

The excretion data for the rats on control and hich molybdenum diets are prescnted in Table Ili. These values represent only oral administration of the isotope. Results from both mature and youne, rats and of tro intervals of time after administration are recorded. The amount of total phosphorus in the urine could not be accurately detemined because of contamination from feei. The total excretion of phosphorus32 was not increased by nolybdemm feeding in the case of the rats. There was an increase in urinary excretion of the labeled phosphorus, but this was not accompanied by an increased excretion throuph the feces. The effect of molybdenum upon phosphorus 32 excre tion in the urine parallels the results observed with oral administration to rabits. Ioth total phosphorus and labeled phosphorus were less in the feces from the rats receivine, molybdemm. The urinary excretions at 1,8 and 72 hours inlicated that nolybdenum in the young rat caused moro rapic excretion of the absorbed labeled phosphorus. There was no increase at 72 hours over that excreted at 43 hours. "ith mature rats, the excretion at 7 ? hours was almost double that at 
48 hours. This is also reflected in the fecal excretion but to a lesser degrec.

\section{TABID 14}

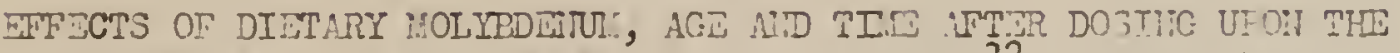
ETCRETIO:T OF ORLIY ADIINISTERED FHOSPHORUS32 BI THS RAT

\begin{tabular}{|c|c|c|c|c|c|c|}
\hline \multirow{2}{*}{ Ration } & \multirow{2}{*}{$\begin{array}{l}\text { Hours } \\
\text { after } \\
\text { Dose }\end{array}$} & \multirow{2}{*}{$\begin{array}{l}\text { Afe } \\
\text { (recks) }\end{array}$} & \multirow{2}{*}{$\begin{array}{l}\text { No. } \\
\text { Rats }\end{array}$} & \multirow{2}{*}{$\frac{\text { Urine }}{\text { D Dose }}$} & \multicolumn{2}{|c|}{ Feces } \\
\hline & & & & & isose & IE total $p$ \\
\hline & 4.8 & $\frac{25}{8}$ & 4 & $\frac{8.60}{603}$ & 27.97 & 47.95 \\
\hline
\end{tabular}

Control

72

\begin{tabular}{lllll}
25 & 2 & 15.72 & 33.59 & -66.63 \\
\hline 8 & 2 & 10.73 & 31.97 & 33.87
\end{tabular}

48

\begin{tabular}{llllr}
25 & 4 & 12.19 & 15.65 & 36.55 \\
\hline & 13.07 & 6.01 & 38.11
\end{tabular}

Hith llo.

72

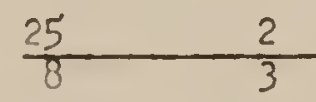

\section{$\frac{22.57}{13.49}$}

$\frac{25.25}{12.70}$

$\frac{55}{38} \cdot \frac{78}{47}$

Tissue Distribution - Data representing the denosition of

labeled phosphorus in the tissues under the differont conititions are surmarized in Tables 15, If and 17. The values reported have been corrected to the averare icicht of the aninals within the groups for which the comparisons are made.

The deposition of thosphorus 32 was very similar for cmparable tissues of tho animals on different rations and there were only slirht differencos which may be attributed to the effects of molytome. The 
per cent of dose of the labeled phosphorus was slightly higher in the liver and kidney of both the rats and rabbits which were on the hich molybdenum diets. The fermur bone of the rabbits receiving nolytudenum accumulated a greater percentare of the administered dose than did the control rabbits, but no similar increase was observed in the rats.

\section{TABLT 15}

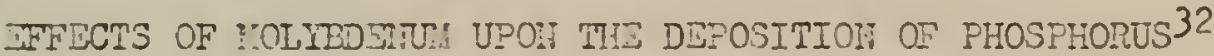
IN SUIECTED TISSUES OF THE RABDIT*

Per Cent of Dose per Gram of Tissue

Tissue Oral Administration (3 rabbits) Intravenous coninistration (2 rabbits)

Control High lio. Control High lio.

\begin{tabular}{lllll}
\hline Blood & 0.016 & 0.012 & 0.018 & 0.014 \\
Liver & 0.105 & 0.125 & .148 & 0.172 \\
Kidney & 0.085 & 0.087 & 0.109 & 0.126 \\
Iuscle & 0.026 & 0.019 & 0.044 & 0.070 \\
Fernur shaft & 0.149 & 0.154 & .136 & 0.271 \\
Femur epiphysis & 0.255 & 0.315 & 0.272 & 0.1888 \\
\hline
\end{tabular}

* 72 hours after administration.

The effects of molybdenum and of tro intervals of tine after administration upon accuralation of phosphorus 32 in the tissues of young rats are shom in Tablo 17. 1330 shom 1s the anount of total phosphorus in the fermurs of these rats. Tho per cent of tho total dose 
ZFEECTS OF DIETARY :OLYBDMIUI UPOIT DEPOSITIOIT OF PHOSPHORUS32 LID TOT.L FHOSPHORUS II!

SEIECTED TIS.JUSS OF MATRE RATS*

Control

High io.

\begin{tabular}{|c|c|c|c|c|c|c|}
\hline Tissuar. & $\begin{array}{l}\text { Dose } \\
\text { Per लm. } \\
\text { Tissue }\end{array}$ & $\begin{array}{l}\text { SDose } \\
\text { Fer } \\
\text { mg. P. }\end{array}$ & $\begin{array}{l}\text { me. } \\
\text { Total } \\
\text { F. }\end{array}$ & $\begin{array}{l}\Rightarrow \text { Dose } \\
\text { Per } \\
\text { Tissue }\end{array}$ & $\begin{array}{l}\text { is Dose } \\
\text { Per } \\
\text { mE. P. }\end{array}$ & $\begin{array}{l}\text { ms. } \\
\text { Iotal } \\
\text { I. }\end{array}$ \\
\hline $3100 d$ & 0.019 & & $\because \cdots$ & 0.030 & & $\therefore \rightarrow$ \\
\hline Iiver & 0.505 & 0.35 & 2.37 & .638 & 0.34 & $? .58$ \\
\hline Kidney & 0.116 & 0.066 & 2.61 & 0.118 & 0.064 & 2.67 \\
\hline iuscle & 0.000 & 0.757 & 2.34 & 0.037 & 0.030 & 3.29 \\
\hline Fernur & 1.17 & 0.020 & 85.87 & 1.167 & 0.028 & 85.39 \\
\hline
\end{tabular}

* 48 hours after adninistration.

* Tissues represent pooled samies of 4 rats.

\% Total phosphorus not determined. 
TLEIE 17

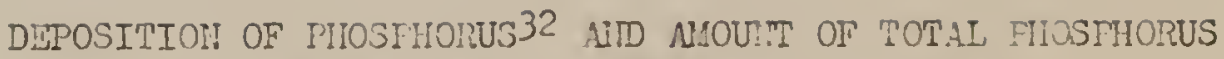

III BILECTD TISSTUS OF YOUIG RITS\%

\begin{tabular}{|c|c|c|c|}
\hline Tissue & $\begin{array}{l}\text { Hours } \\
\text { after } \\
\text { Dose }\end{array}$ & $\begin{array}{r}\text { Per } \\
\text { Control }\end{array}$ & $\begin{array}{l}\text { er Gran of Tissue } \\
\text { High No. }\end{array}$ \\
\hline Blood & $\frac{48}{72}$ & $\frac{0.026}{0.044}$ & $\frac{0.029}{0.043}$ \\
\hline Liver & $\frac{48}{72}$ & $\frac{0.456}{0.375}$ & $\frac{.507}{0.363}$ \\
\hline Kidney & $\frac{48}{72}$ & $\frac{0.211}{0.378}$ & $\frac{n .226}{0.338}$ \\
\hline
\end{tabular}

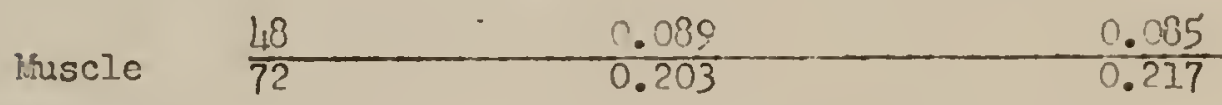

\begin{tabular}{|c|c|c|c|c|}
\hline Dose & $\begin{array}{l}\text { i Dose } \\
\text { Por }\end{array}$ & $\begin{array}{l}\text { mg. } \\
\text { total }\end{array}$ & If Dose & $\begin{array}{l}5 \text { Dose } \\
\text { rer }\end{array}$ \\
\hline
\end{tabular}

\begin{tabular}{llllllll} 
& 1.8 & 2.81 & 0.046 & 60.33 & 2.96 & 0.058 & 56.96 \\
\cline { 2 - 7 } & Femur & 3.49 & 0.057 & 60.90 & 3.36 & 0.030 & 47.75
\end{tabular}

* Tissues represent pooled samples of 4 rats at 48 hours and 3 rats at 72 hours. 
of labeled phosphorus found in the tissues at 72 hours vas freater than that found at 48 hours in all of the tissucs except the liver. These increases rere comon to the rats on both rations; thereforc, no specific effect of nolybdenum upon the rate of accurnlation can be obscrved in the young rats. The increase in the labeled phosphorus of the bidney at 72 hours is also reflected in the urinary excretion at 72 hours.

The decrease in the amount of total phosphorus and the increased specific activity of the bone of young rats receiving molybdemu (Table 17) indicate a greater rate of exchanfe of pinosphoms and more interference with nornal phosphorus deposition in the young rat than in the mature rat.

hen the concentration of labeled phosphoms per unit of total phosphorus was calculated there mas little difference in the specific activity of the tissues of rats on the different rations (Table 16). The difference in the per cent dose per milligran of total phosphorus in the bone of old and young rats reflects the larger anount of total phosphorus present in the bone of mature rats.

There appears to be a species difference in the tissue accumulation of labeled phosphoms. The soft tissues and the femur bones of the rats accumulated a considerably rreater proportion of the dose of the isotope per unit of tissue than lid the rabbit tissues. i portion of this difference $\mathrm{nar}$ be attributed to tho difference in time aftor administration of the isotope. Bcperiments imolvine a laree muber of animals should be undertalcen in order to establish whether such a 
difference exists.

The total phosphorus content of the fermur bones from 17 rabbits receivin: different dictary Ievels of molytudemu has been deternined. The results wich represent mean values for the muber of bones examined are surmarized in Table 18. There were wide variations in individual rabbits, but the averares indicate a sligit decrease in the phosphomus content of the bones of rabbits which were receiving nolybdenum. Tho of the rabbits in the rroup receiving copper and nolybdemum had previously received nolybdemum without copner supplementation. They had developed typical symptoms of taxicity, one of wich exhibited the foreleg trouble. Both rabbits were treated with copper and the copper supplementation was contimed until they were sacrificed and the total phosphorus of the bones detemined.

\section{T.BI. 18}

TOTRL PHOSPHORUS CONTEIT OF FEMR BOITS OF PABBITS

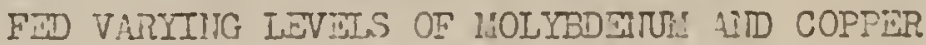
(mg por cram fresin tissue)

$\begin{array}{ll}\text { Ration of } & \text { Mo I. } \\ \text { Rabbits } & \text { por iram } \\ & \text { Tissue }\end{array}$

\begin{tabular}{|c|c|}
\hline 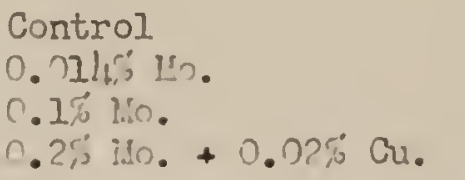 & \\
\hline
\end{tabular}


It appears that the effects of molybdenum upon the netabolism of phosphoms under the conditions of this experinent rere limited to alteration in the excretion of phosphoms. inile there were slight chances in the deposition of labeled phosphorus in some of the tissues, these differences were not simiricant and not as pronounced as the changes in excretion which have been described. It should be noted that none of the animals exhibited symptoms of molybdenum toxicity at the time when these phosphorus metabolism studies were undertal:en. The quantity of molyddemun $\left(0 . I^{\prime}\right)$ fed to the rabbits in this experiment had produced toxicity in other young rabbits and had produced moderate symotoms in some of the rabbits mich were later used for these phosphorus studies, but none exhibited any toxic symptoms at the tine of this experiment. If the phosphorus studies had been made whon evidence of molybdenum toxicity first appeared, it is possible that the effects of molybdenum may have been exhibited in a different manner. 
The role of molytodenum in the mutritjon of the rabit has been studied throgen joservalions of the effect of sun-lementary molybdenum in the diet. A molybdemu toxicity was proxuccd and the symons have been doscribed. Anemia was characteristic of the toxic syndrome and was fur iner stukied witin respect to hmorlobin, red blood cell counts and blood volume. The therapeutic action of copper in curins the toxicity mas studied by rollowing, the chrnees resultinf from conpor therapy. Growth experiments were coniucted with meanin robbits an\& rats receiving varjin levels of molybdenum. Some cffects of molybdenum upon the netabolism of phosphorus rere studied tinrougi ba? ance experirents and tissue cistribution of radioactive phosphorus 3 ?

Some of the rcsults have been of a confirmatom nature rihile other findinrs have demonstrated actions of moljbdenum which anocar to be specific for the rabbit. These obsorv"tions have been relatcd to resuits of coneriments inth other species and have been discusscd ith respect to their possible imlications. Conclusions wich may be marle frm these experiments are summrized in the rollowing statements:

1. iolotodemm is toxic to rrbbits. Unier conditions of this experinent, 0.1 per cont added to a naturel ration was toxic to younr, rabits and :ras borderline in toxicity for mature rabbits. Tro-tenths and C.L por cont nolytudenum was toxic to 27.1 arres of rabuits. 
2. :olyudenum toxicity in the rabbit was characteriaed by loss of reifht, anemia, alopecia and dernatosis and abnomal bone development.

3. The abnomal bone developmont was observod in youn rabbits receivin 0.1 per cent or more nolybdenum. The front lers of affected rabbits becnme reakened so that they could not be maintained in a nomal position and could not support the body. Observed in the abnomality were swollen joints, bent and tristed bones, slipped joints and slipped tendons.

4. Bxcess nolyodemur caused anerie :ith low homoglobin and low red blooc cell counts, but did not affect the blood volume of rabbits.

5. Dictar. copner was effective in preventin molybdem toxicity and in curing all symptons of the toricity excopt the front leg abnomality.

6. lolytudemm tended to increase the accumulation of copncr in tine iver of esperinental rabbits.

7. In ljodemum Ied at the level of $0.0 \mathrm{~L}_{1}$ and 0.0 ? per cent in a sinolified dict retarded the crowth of malc rats, but did not simificantly rostrict the proith of fomalo rats.

- Vitamin 4 an' vitanin I did not improve the morth of male rats fed $r .01 !$ and 0.72 ner cent molybdenum.

9. Lolybdemm did not affect the renroduction of rats under conditions of this experiment.

10. IIopecin inich was confined to thinuin of the hair over the bacl: was obscived in sme malc rats reccivin dictary molytuemu- 
11. There was an increase in urinary and fccal excretion of orally administercd radioactive phosphorus ${ }^{32}$ in rabuits receiving ?. $1 \stackrel{\circ}{\mathrm{c}}$ molybolenum in the ration.

1?. Nolybdemun fed at a level of 0.014 and 0.0 ? por cent in the diet of rats incrensed the urinary excretion of phosphomus? but did not increasc fec ?] cxcretion.

13. The clistribution of phosphomus 32 and the amount of total phos horms in the tissues of rabbits and rats was not simificantly affected by the presence of molybdenum in the ration.

\section{Recommendations for Future Rescarch}

The results of this research have been presented and discussed with relation to results of similar rescarch :ith sther species. In adiition to the result. which have becn recorded, other obscrvations have been made which imply still othor actions of molybdenus. These proposals, if submittod to properly desimed resench, should provide additional approaches to the study of the role of molybdenum jin the animal orfanian. Some recomendations for specific research in this. ficld follow.

1. Differences in species tolorance and lifferences in the manifestration of nolybdionum toxicity have been established for severa? species. These differont responses to nolybicmu shou?d be more specifically relater to the nirgiolory of the anims. in example of the variations in species response is tho sccurrence of severe dirrher in some spocies and absonce of 
such a symtm in others when molybdenum is in excess.

? Further studies vith rabbits should croloy simplificd or purificd diets so that the intai:e of copper may be linited to a maller amount.

3. The abnomal development of front legs in youne, rabbits suggested that molybdenum may create a manganese deficiency or may interfere "ith the metabolism of manganesc. Tisis bone abnormality should be studiod rith relation to manganesc or to othor nhysiolorical functions concernod "ith bone formation.

L. $\therefore$ comarison of the gronth of rats in this study rith provious experinents indicrted that an improved nutritional status of the animl increases the tolerance to molyodemas. The effects of nolybdomu should be furthor related to nutritional status of the animal.

5. The more adverse effects of molytodonun upon youn anirals indicated an action of molybdenum ass cisted with the gronth process.

- The anemia Ith 1 r red blool cell counts in rabbits surpestod that crbalt or vitamin $B_{12}$ might be deficinnt. It slivuld be determined whethor the anemia vill respon: to vitanin D12 theraps.

7. The tipe of aneria which develops in the difforent species shou : : be more specifically idontified.

R. The mparont nomal libido in male rabits sufferine from nolvtudemm toricity sugrested that the effoct ur in reproduction 
in rabbits may not parallel the effects observed in other species.

' Factors responsible for the greater toxicity of molyodonum when fed ith reen succulent feed could be studied on a laboratory scile usine the rabbit as a laboratory aninal.

1. Fhosphoms netabolism studies indicated that molybdemum interfered with absorption of phosphorus. ldditinnzl balance studies made at a time when animnls shor symntoms of nolybdenum toxicity should cstablish more clearly the effect of molybdenum upon phosphorus absorption and excretion. 


\section{BIBLIOGRAFHY}

1. Anderson, 4. J. 1940. Hol-jodem and other fertilizers in pasture development on southern tablelands of ITe:r South "Tales. Joumal of the Australian Institute of Amricuitural Science $\mu_{i}:$ iio. 1, 28-33. (Chemical Abstracts $42: 9034$. 1948)

2. Anderson, $\dot{4}$. J. and 7 . Spencer. 1950. Wolybdemum in nitrogen metabolism of lemunes and non-leEmes. The Australian Journal of Jcience. Research Series ¿. Ziolorical Scicnces $3(4): 1,14-430$

3. Inderson, A. J. and Y. I. Thomas. 1946. Plant responses to molybdemm as a fertilizer. I. Iolytudenum and syzbiotic nitroren fixation. Comormealth of Australia Council for Scicntific and Industrial Pesearch Bulletin 108: 7-?4.

4. Archibald, J. G. 1051. lolybdenum in cors' mill. Journal of Dairy Scionce 3L: 1026.

5. Arnon, D. K. and F. R. Stout. 1939. Lolyidemm as an essential element for higher plants. Mant Physiology 14: 599-602.

6. Association of Official pricultural Chemists. 1950. Official and Tentative Ietinods of inalysis. pn s-1n. 7th ikition. issociation of Official irricultural Chemists, iashington, D. C.

7. Barker, I.., 1. H. Ennor and F. Harcourt. 1950. The catalytic effect of molybdate on the breaidoin of phosphocreatinc. The Australian Journal of Science. Research Series 3 . Biolorical Sciences 3: 337-345.

8. Barshad, Isaac. 1943. liolyodenum content of pasture plants in relation to toxicity in cattlo. Soil science 66: 137-185.

9. Beath, C. A., I1. F. Eopson and C. ;. Silbert. 1935. Sclcrium and other toxic mincrals in soils and vegetation. yoming Apricultura? Smeriment Station Eulletin 206: 36-37.

10. Eortels, H. 1227. Hiochomische Zeitschrift 182: 301-338. Chomical Activities of Fungi. pr. 255. 194?. Acadomic Pross Inc., lier Yor\%, Ner York.

11. Bortel3, 1:. 1030. "Oolytudenum as a catalyst in the biolorical flxation of nitrogen. Irchiv fur :1)robiologie 1: 333-342. (Chanica' lustracts 26: 2481. 103? 
12. Bortels, H. 1937. The effect of molybdomm and vanadium compounds on lemunosac. Archiv fur ilikrolioloric 6: 13-26. (Chemical bstracts 31: 6395. 1937)

13. Bortels, H. 1536. Importance of moly3jemm, vanadium, tunrsten and other ash constituents for nitrogen-fixin and other microorcanisms. Zentralblatt fur Balterioloric, Farasitenlunde and Infeltionslrain'theiten o5: 193-213. (Chemical Abstract3 31: 1542. 1937)

14. Bossard, $\because$ 104!. 1cti $n$ of inhibitors on almond phosphatase. IV. Action of molrbiates. Bulletin de la Societe de Chemie Biologique 26: $464-469$. (Mremical Abstracts 10: 3144. 1946)

15. Bossard, 1. 10/47. Action of zolybdates on various enzymes. Bulletin de la societe de Chemie Biologique 29: 218-?21. (ChemicaI lbstracts $41: 6586$. 1947)

16. Brenchley, $\because .{ }_{\text {. }}$ and $K$. iarington. 1942. V-lue of molybciemrs for lettuce. lature 표: 196.

17. Britton, J. . and I. Goss. 1946. Chronic molysdemun poisoning in cattle. The Journal of the Inerican Veterinary Iledical issociation 103: $176-178$.

18. Brourer, 5. 1926. IJote on anemia, urobilimuria and intestinal haemorrhage in rabbits in consequence of exclusive nutrition wit! cor's and roat's mill. Tho Biochemical Journal 20: 105107.

19. Burl, D. and C. K. Horner. 1936. The role of traces of molybdemum in the physiolong and agrobiolom of azotobacter. Soil scicnce Society of merica, Froceedinns 1: 213-21).

20. Cohen, 3. and A. 11. Smith. 1919. The colorimetric detcrmination of hemorlobin. The Joumal. of Biolopical Chemistry 3f: 1:8\%496.

21. Comar, C. L., Leon Sinper and G. K. Davis. 194. I. Ioljzolenum metabolism and interrelationships ith copner and phosphorus. The Journal of Ifolorical Chenistry I80: ?13-cnn.

22. Courtois, J. and $\%$. Jossard. 194. Action of inhibitors on alroni phosthatase. IV. hetion of molyudates. Bulletin do la Societe de Chemie Diolorique 26: 1,61:-1,6r. (Chonical Abstract3 1.0: 3214.4. 19!.6)

23. Craige, A. H., Jr. 1015. Ipproved Laboratory Technic. L:th "dition. By J. ". holmer and Frod Bocrner. Appleton-Century-Crofts, Inc., Ile" York, liew Yor': pp. 5n. 
24. Cuninghan, I. J. 1931. jome biochemical and physiolorical aspects of comer in mimal nutrition. The Biochenical Journa? 25: 1267-120!.

25. Cunningham, I. $\therefore$ 1950. Copper and molydemum in relation to diseascs of cattle and shcep in licr Zealand. Copner llotabolism, A Jymosium on Animal, Plant and Soil Relationships. Exlited by ". . ". Iroy an: Sentley Glass. The Johns Hoplins Press, Baltimore, "arrland. pp. 24,6-273.

26. Davis, \%. and ". Kannan. 19117. Copper netabolism with relntion to alkaline bloor phosphatase and blood ascorvic acir. Jourmal of inimal jeince $6: 48 \%$.

27. Davis, 1. 1950. Influenco of copper on the metabolism of phosphorus and molybdenum. Copper ietabolism, A Symosius

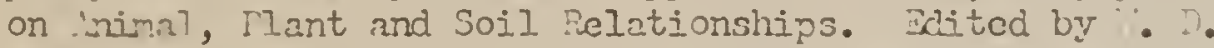
:CHroy and Sentley Glass. The Johns llopkins Eress, Baltimore, liaryland. po. 216m?2 .

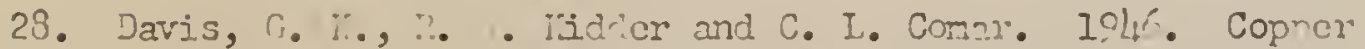
deficiency in cattle. Journa of inimal icience $5: 393$.

29. DeRose, H. "., ". 3. Eisemenrer and ". 3. Ritcilic. 193?. The comparative mituitive effects of copper, zinc, chromiun and moljodeme. 'assachusetts impicultura' zxerimont jtation Bulletin 355: ?0.

32. Dicl., $\therefore$. and L. $\therefore$. Jul7. 1945. Some preliminny observations on the effect of nolyzdenum on conper netabolis' in herbivorous animals. The Australian Voterinary Jounul 17: 70-7?. (Chemical Abstracts 1 2: 5965. 191.8)

31. Di Palna-Casti-lione, $\therefore$ and i. Landi. IrLr. The action of moljodenus on nicroomanisms and on veretation. imnali Facolta Mraria Universita di risa ?: 313-33\%. (Chonical ibstracts !1: 5050 . 1950)

32. Droa, . $\therefore$ 1935. Jpectrun analysis of hen erras and chici: tissues. The journal of iutrition 10: 351-355.

33. Drea, . 1934. Spccturn analysis of rilk ashes. The Joumal of :utrition 8: 22?-?3l:

34. Droa, … 193?. Jpectinum analyses for trace elements in the asies of human, poat and cor mill. The Journal of lutrition 16: 375-331. 
35. EJis, G. II., S. I. Jmith and Eiabbeth $\because$ G.tes. 1947. Further studies of manganese deficiency in the rabbit. The joumal of intrition 3L: ?I-3l.

36. Fairhall, I. I., R. C. Durn, 11. ¿. Sharpless and E. A. Fritchard. 191.5. Toxicity of molybdenum. United States Lublic Health Bulletin 293: 1-36.

37. Ferguson, ". S. 194: "Teart" of Somerset: A molyudenosis of farm animals. Froceedinrs of the Iutrition jociety (Ingland and Scotland) I: 215-?20. (Chemical ibstracts 39:3616. 1945)

38. Ferguson, \%. 3., is I. Iewis and S. J. "Tatson. 1943. The teart pastures of Somerset. I. The cause and cure of teartness. The Journal of Aericultural Science 33: 44-51.

39. Ferguson, $i$. ., 1. H. Levis and 3. J. "iatson. 1938. Action of moljbdemm in mutrition of milhinf cattle. Nature $U_{11}: 553$.

40. Forsee, ". I. and T. C. Mmin. 19ls. Innual Report, Forida Agricultural ixperiment Station. pp. 187.

41. Franice, $\tilde{K}_{\text {. }}$ and 1. I. Loxon. 1237. The toxicity of orally ingester arsenic, selenium, telluriur., vanadium and molytdemun. The Journal of Thamacology and Ixperimental Therapeutics 61: 89-10?.

4. Gray, Louisc $F$ and C. H. Dlis. 1950. Some interrelationships of copper, molyidemm, zinc and lead in the mutrition of the rat. The journal of irutrition 40 : $411-452$.

43. Green, : $\because$ 1950. ifincral elcnents in relation to health of ruminants in Groat Britain. Congres International de Iniustrie Agric:? ture, Brussels 2: 71-86.

W. Greccrsen, :. T. 19lil. A practical method for the determination of bloori volume inth dye T-1824. The Journal of Laboratory and Clinfes? liedicine 29: 1266-1286.

45. Hevesy, G. and K. Zerahn. 19/,2. Dotomination of the red corpusclo content. icta Physiolorica scondinavica L: $376-384$.

46. Hoarland. D. $\mathrm{D}$. 1941. Water culture experments on molyodemm and copier ieficiencies of fruit treos. Americn Society for Horticultural icience, Procecdings 38: 8-1?.

47. Jensen, li. I. 1848. Influonce of molytudenum, calcium and ar.ar on nitrocen flxation by nzotobacter indlcum. Proccedinrs of the Iinnean Socioty of llo: Scuth iales 72: 299-310. (Chamical ibstracts $4,2: 4643$. 291,8) 
48. Jensen, H. I. and R. C. Betty. 19li2. Iitrogen fixation in leguninous plants. III. The importance of molybdemm in symbiotic nitrogen fixation. Procoodines of the Linnean Socicty nf llew South inles 68: 1-8.

4?. Jeter, $:$. . 1. 1951. The influence of varying levels of molybdemu upon grorth, reproduction and mineral netabolism in animals. Doctor of Philosony dissertation, University of Florida.

50. Kobozer, ii. I. 10l. Catalase action of various cataly3ts. The cotalytic activity and structure. Acta Physicochimica

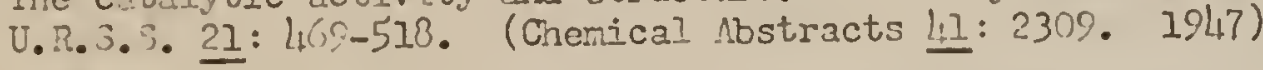

51. Kulvich, ?. 1951. Interrelationships of molybdemu, copper and zinc in the simple-stomached animal. Doctor of Philosophy dissertation, Iniversity of Morida.

5?. Lewis, A. H. 1943. The teart pastures of Sonerset. IIT. Reducinr the teartness of pasture herbage. The Joumal of Aericultural Science 33: 58-63.

53. Iewis, A. II. 1943. The teart pastures of Somerset. II. Relation betreen soil and teartness. The Journal of Lricultura? Science 33: 52-57.

54. Lorenzen, Jvelym J. and 3. E. Smith. 1847. Copper and manranese storare in the rat, rabbit and guinea pig. The Journal of iutrition 33: 1/3-15l.

55. IcGorran, J. C. and I. . Brian. 1947. Inhibition of catechol bacteriostasis by nolybdates. l'ature 159: 373.

56. Mantin, . R. 1923. The occurrence of molybdemu in the egE of the domostic fowl. The llerical Joumal of lustralia 2: 87.

57. Liarston, If. I. 1952. Cobalt, copper and molybdenur in the mutrition of animals and plants. Physiolorical Revicrs 32 : 66-1?1.

50. Barston, 1. ?.. 105ก. Problems associated rith copper deficiency in muinuts. Copper Lotabolism, A symposium on ininal, Ilant and Soil Relationships. The Johns Hoptins Press. Baltimore, liarylanl. חp. 230-245.

59. l:eulen, "i. tor. 1931. istribution of noljbdenum in nature. Tecucil des Iravaux Chimiques 50: 491-504. (Chcmic37 nbstracts $25: 3392.1931)$

6n. Leulen, li. ter. 193?. Distribution of nolybdcmm. Inture 130: $966-9 i 7$. 
61. lhuir, "i. 12. 19/1?. The teart pastures of Sonerset. The Veterinary Journal $97: 3.37-40 n$.

62. Hachman, li. C., ".. '. James, J. i.. Joore and :.. I. Jvans. 1950. $\therefore$ comparative study of red cel. v volunes in human subjocts with radioactive phosphoms tarced red cells and $\mathrm{T}-1824$ dre. The Jourmal of ulinical. Investigation 20: 258-26l.

63. Jeiland, J. 3., F. I. Strong and C. A. Elvehjer. 194i. Jolybdemm in the nutrition of the rat. The Joumal of Jiolorical Cnemistry 17?: 431-1:39.

6l:. Piper, C. S. 194ก. Erolybdenum as an essential element for plant rrowth. The Journ.l of the nustralian Institute of lericiltural Science 6: 162-164. (Cherical ibstracts 35: 6618 . 1942)

65. Pussell, F. C. 1914. liincrals in pasture deficiencies and excesses in re? ation to animal heal.th. Technical Cormunication :.o. 15. Impcrial Bureau of inimal Iutrition, Rowett Institute, Buclisburn, Aberdeen, scot]and.

66. Sande11, $\therefore$. E. 194h. Colorimetric determination of traces of netals. Interscience Publishers, "iew York, liew York. pp. ’212.5.

67. Sandel1, :. . 12lil. Colorimetric detcmination of traces of metals. Interscience Publishers, llew Iork, Ien: Tork. np. 330338.

68. Shirley, R. L., Piley D. Arens and G. K. Davis. 1950. Deposition and aljuntary excretion of phosphorus 32 in stec.ss on hich mol-tudemm and copper dicts. Joumal of inimal science ?: 55?55 .

69. Sh1rley, ". J., Rilcy . Orens and C. K. Davis. 1951. 17imentary excreti in of phosphorus 32 in rats on hirh molyodenum and coppor diets. The joumal of liutrition 14: 595-602.

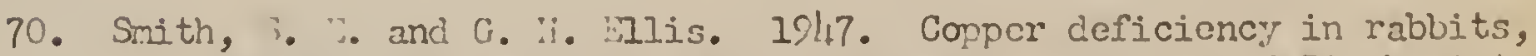
achromotricia, alopecia anl dernatosis. ircilives of Biocheristry 15: $81-38$.

71. Smith, 3. 2., Kry lledicott and G. H. Elis. 194h. Mancanose deficioncy in the rabbit. prchives of Biochemistry l1: 281-233.

7?. Steinberr, ?. 1236. Relation of accessary groirth substances to heav motia ${ }^{1}$ inc ${ }^{7}$ udine, molybdenum in the mutrition of isperfilizus niger. Journal ar Mrricultural Research 52: 1,38-1,16. 
73. Steinbere, $\therefore$ ¿ 1937. Pole of nolybdems in the utilization of amonium and nitrate nitroren by spercillus niger. Journal of Arricultu'a? Rescarch 55: 891-002.

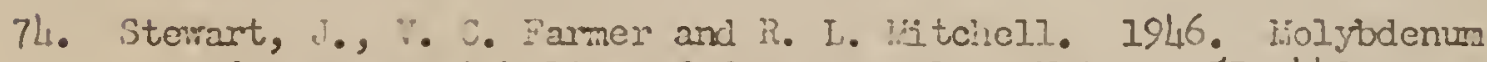
and copper metabolism of fam aninals. iature 157: 442 .

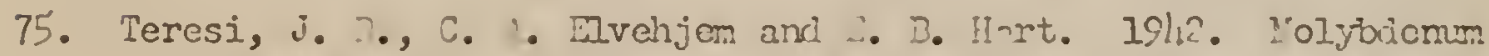
in the nutrition of the rat. The Ancrican Joumal of Fnysiolocy 137: $501-509$.

75. Thomas, J. and 3. Hoss. 1951. The effect of orally administered molydenum on prowth, spermatorenesis and testes histolory of youn- dairy bulls. Joumal of Diry Science 314:929-934.

77. Trnka, R., F. Frantek and L. Praskac. 19lh. The effect of trace elenents on the development of plants. Chemisches Zentralblatt II, 1733. (Chemical Abstracts 37: 6307. 1943)

73. Trumble, II. C. 1950. Trace clenents and phosphate in herbage plant nutrition. Copper Ietabolism, 1 Symposiun on Animal, Mlant and soiz Relationships. Dited by ... D. "ci.jroy and Bentley Class. The iohns foplins Fress, Baltimore, karyland. pr. $336-36 r$. 


\section{BIOGRAPHICAL ITAIS}

Lewis Roberts Arrineton mas born hay 1, 1919 at Kirlisey, Greemrood County, South Carolina. He was raduated from high school at liinety-Six, South Carolina in May 1936. He entered Clenson Collere in 1936 and received the Bachelor of Science degree from that institution in June 1940. Folloning graduation from Clemson Collere, he entered Virginia Polytechnic Institute in September 1940 and received the liaster of Science degree in June 1941.

"hile in residence at Virginia Polytechnic Institute he held a teaching fellowship. During "Norld War II he served four ycars as a comissioned officer in the United States Arny. In September 1946 he ras employed as Assistant Frofessor in the Department of Dairy Science at the University of Florica. He held this position until entering graduate school at the University of Florida in Febıuary 1950 to berin studies leading toward the Doctor of milosophy derree. Thile in residence for this degree he held a grant-in-aid followship from the litrition Foundation, Inc.

He is a member of Mpha Zeta honorary fraternity, Sigra Xi Society and Phi Sicna Biological Society. 
This dissertation was prepared under the direction of the Chairman of the candidate's Supervisory Committee and has been approved by all members of the Committee. It was submittal to the Graduate Council and was approved as partial fulfilment of the requirements for the degree of Doctor of Philosophy.

Date Lune $9 / 90^{-2}$
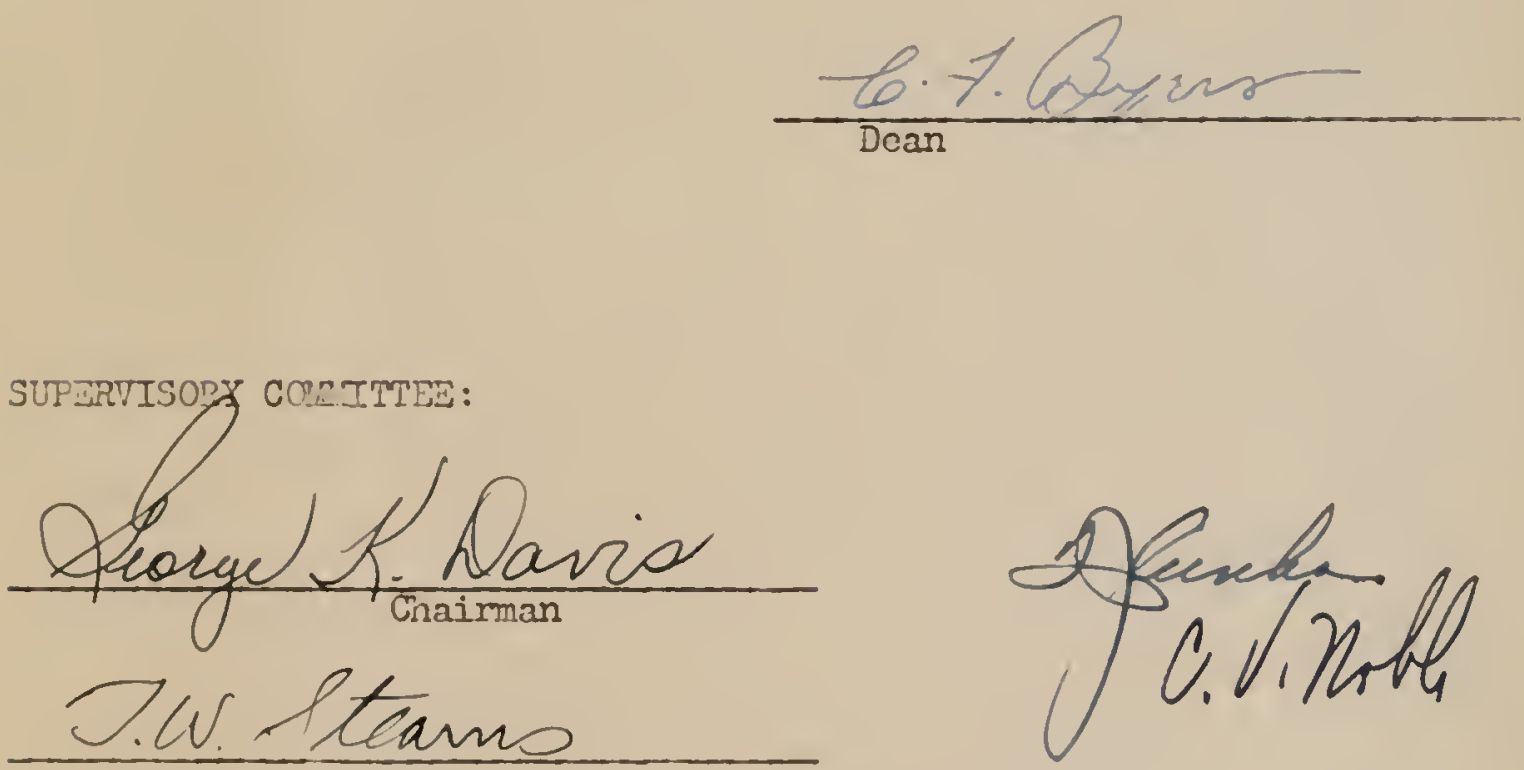

haber h. Emerson

Tared U Wall

R.B.Beker 
